\title{
Targeting Tumor Microenvironments for Cancer Prevention and Therapy
}

\author{
Li V. Yang1,2,3, Reid D. Castellone ${ }^{1}$ and Lixue Dong ${ }^{1}$ \\ ${ }^{1}$ Department of Internal Medicine, Division of Hematology/Oncology, \\ 2Department of Anatomy and Cell Biology, Brody School of Medicine, \\ East Carolina University, Greenville, North Carolina, \\ ${ }^{3}$ UNC Lineberger Comprehensive Cancer Center, Chapel Hill, \\ North Carolina, \\ U.S.A.
}

\section{Introduction}

Solid tumors comprise not only cancer cells but also host stromal cells, such as vascular cells, inflammatory/immune cells, and cancer-associated fibroblasts. The crosstalk between cancer cells and stromal cells plays an important role in tumor growth, metastasis, and response to antitumor therapy (Hanahan and Weinberg, 2011; Joyce and Pollard, 2009; Petrulio et al., 2006). Cancer cells with oncogenic mutations are central to tumor formation. Endothelial cells in tumors form new blood vessels (angiogenesis) which bring oxygen and nutrients to the growing tumor (Ferrara and Kerbel, 2005), and also regulate leukocyte infiltration and tumor cell metastasis (Chouaib et al., 2010). Inflammatory cells have both tumor-promoting and tumor-preventing effects (Grivennikov et al., 2010; Hanahan and Weinberg, 2011). Fibroblasts are the most abundant cells in the tumor stroma and have been demonstrated to have tumor-promoting activities (Bhowmick et al., 2004). Moreover, cancer cells within tumors are heterogeneous and composed of distinct subpopulations with different states of tumorigenicity. One subpopulation of cells that has recently been extensively studied is the cancer initiating cell or cancer stem cell (CSC) (Cho and Clarke, 2008), which exhibits high capacity of generating new tumors.

The microenvironment in solid tumors is very distinct from that in normal tissues. Due to deregulated cancer cell metabolism, highly heterogeneous vasculature and defective blood perfusion, the tumor microenvironment is characterized by hypoxia and acidosis (Cairns et al., 2006; Gatenby et al., 2006; Gatenby and Gillies, 2004). The uncontrolled proliferation of tumor cells results in a growing mass that rapidly consumes oxygen, glucose and nutrients (Gatenby and Gillies, 2004). When an oxygen diffusion limit is reached, some regions of a tumor become hypoxic. Cancer cells rely heavily upon glycolysis ('Warburg effect') to generate ATP and metabolic intermediates for biosynthesis (Gatenby and Gillies, 2004; Vander Heiden et al., 2009). There is much evidence to link the connection between the adaptation to hypoxia and the development of an aggressive tumor phenotype in both experimental and clinical settings (Chang et al., 2011; Gatenby and Gillies, 2004). In addition to hypoxia, the existence of acidosis is a defining hallmark of the tumor microenvironment. 
This condition arises mainly due to an increase in the production of lactic acid by glycolysis along with other proton sources (Gatenby and Gillies, 2004; Helmlinger et al., 2002; Yamagata et al., 1998). Acidosis is a selection force for cancer cell somatic evolution, modulates cancer cell invasion and metastasis, and affects the efficacy of some chemotherapeutic drugs (Cairns et al., 2006; Gatenby et al., 2006; Gatenby and Gillies, 2004).

Here we will describe cellular heterogeneity, hypoxia, and acidosis in the tumor microenvironment, and discuss some recent progresses in targeting tumor angiogenesis, inflammation, hypoxia and acidosis-related pathways for cancer prevention and therapy.

\section{Tumor microenvironments and cancer progression}

\subsection{Complex cellular components in solid tumors}

Tumor is an aberrantly proliferating tissue that contains cancerous cells and host stromal cells such as vascular cells, inflammatory cells, and fibroblasts. These cells are crucial for cancer initiation, progression and metastasis and have been exploited as targets for cancer therapy and prevention (Ferrara and Kerbel, 2005; Fukumura and Jain, 2007; Hanahan and Weinberg, 2011).

\subsubsection{Vascular cells}

Tumor blood vessels, like normal vessels, are composed of endothelial cells, pericytes/smooth muscle cells and basement membrane. However, all of these components are morphologically and/or functionally different from the normal counterparts (Baluk et al., 2005).

Tumor-associated endothelial cells (TECs) are the major player in the formation of tumor vasculature through sprouting from pre-existing blood vessels (a process called 'angiogenesis'). During blood vessel formation, endothelial cells proliferate, migrate and form the inner layer of a lumen, followed by basement membrane formation and pericyte attachment. Angiogenesis is stimulated by excessive pro-angiogenic factors secreted by tumor cells or stromal cells in an oxygen-depleted microenvironment. Moreover, bone marrow-derived endothelial progenitor cells recruited to tumor stroma can contribute to blood vessel construction by incorporating into vessels (Lyden et al., 2001). New blood vessel formation is critical for tumor development and progression, as it delivers nutrients and oxygen to growing tumor and removes metabolic wastes. In addition, vascular endothelial cells form a barrier between circulating blood cells, tumor cells and the extracellular matrix (ECM), thus playing a central role in regulating the trafficking of leukocytes and tumor cells (Chouaib et al., 2010). In this regard, endothelial cells are critical for boosting a host immune defense against cancer cells and for controlling tumor metastasis. However, the 'gate-keeping' function of endothelial cells in tumors is heavily compromised. TECs are not tightly associated with each other, resulting in wider interendothelial junctions that cause plasma leakage and hemorrhage (Hashizume et al., 2000). Consequently, tumor vasculature is often leaky and less efficient in blood perfusion, leading to high interstitial fluid pressure, hypoxia and acidic extracellular $\mathrm{pH}$ that significantly affect the delivery and efficacy of chemotherapeutic drugs. The leaky blood vessels also facilitate the intravastion of tumor cells and promote tumor metastasis. 
TECs are different from endothelial cells in normal tissues at several aspects. It has been reported that human hepatocellular carcinoma-derived endothelial cells, when compared to the ones from adjacent normal liver tissue, show increased apoptosis resistance, enhanced angiogenic activity and acquire more resistance to the combination of angiogenesis inhibitor with chemotherapeutic drugs (Xiong et al., 2009). Studies have also revealed distinct gene expression profiles of TECs and identified cell-surface markers distinguishing tumor versus normal endothelial cells (Seaman et al., 2007).

In blood vessels, pericytes are smooth muscle cell-like cells that cover the vascular tube. They are intimately associated with endothelial cells and embedded within the vascular basement membrane, and play an important role in the maintenance of blood vessel integrity. Pericytes in tumors are different from normal ones: in tumors, pericytes are often less abundant and more loosely attached to the endothelial layer (Abramsson et al., 2002; Morikawa et al., 2002). The abnormality in pericytes weakens the vessel wall and increases vessel leakiness. Pericytes express several markers, though none is pericyte-exclusive, including a-smooth muscle actin (aSMA), platelet-derived growth factor receptor- $\beta$ (PDGFR- $\beta$ ) and NG2 (Gerhardt and Betsholtz, 2003; McDonald and Choyke, 2003). PDGF-B signaling is important for pericyte recruitment and attachment to endothelial cells during vascular development (Abramsson et al., 2002; Abramsson et al., 2003).

\subsubsection{Inflammatory/immune cells}

Tumors are often infiltrated by inflammatory cells, such as macrophages, neutrophils, lymphocytes, mast cells, and myeloid progenitors. This phenomenon was initially observed by Rudolf Virchow more than a century ago and thought as an immunological response attempting to eliminate cancer cells. Whereas immune cells play a role in recognizing and eradicating early cancer cells (Kim et al., 2007), mounting evidence has also shown that inflammatory cells within tumors can enhance tumor initiation and progression by helping cancer cells acquire hallmark capabilities (Grivennikov et al., 2010; Hanahan and Weinberg, 2011). Inflammation is considered as an 'enabling characteristic' of tumor biology (Hanahan and Weinberg, 2011).

Pathological studies show that the abundance of certain types of infiltrating inflammatory cells, such as macrophages, neutrophils and mast cells, is correlated with poor prognosis of cancer patients (Murdoch et al., 2008). Tumor associated macrophages (TAMs), along with mast cells, neutrophils and other immune cells, produce cytokines (e.g. TNFa and IL-1), chemokines (e.g. CCL2 and CXCL12), angiogenic factors (e.g. VEGF, PDGF, FGF and IL-8), and matrix-degrading enzymes (e.g. MMPs, cathepsin proteases and heparanase) (Grivennikov et al., 2010; Karnoub and Weinberg, 2006). Some inflammatory cells, particularly neutrophils, also generate reactive oxygen and nitrogen species. These bioactive factors promote cancer cell proliferation, invasion and resistance to apoptosis through, for instance, the interleukin-JAK/STAT pathway (Ara and Declerck, 2010), and induce new blood vessel formation in the tumor. Extracelluar matrix-degrading enzymes promote cancer cell invasion and metastasis, whereas accumulation of reactive oxygen and nitrogen species can cause DNA mutagenesis, suppress DNA repair enzymes, increase genomic instability, and aggravate cancer progression. 
While the tumor-promoting effects of infiltrating inflammatory cells have been well documented, certain types of immune cells, particularly cytotoxic T cells and natural killer cells, exhibit anti-tumor activities. The high numbers of these cells within a tumor predict a favorable prognosis (de Visser, 2008; Fridman et al., 2011). Immune surveillance is considered as an important mechanism to inhibit carcinogenesis and maintain tumor dormancy (Kim et al., 2007). Evading immune destruction by downregulating tumor antigens, suppressing immune cell function and other means is an emerging hallmark of cancer cells and plays important roles in cancer progression and metastasis (Hanahan and Weinberg, 2011). With regard to cancer therapy, blockade of CTLA-4 (cytotoxic T lymphocyte-associated antigen 4), a negative regulator of $\mathrm{T}$ cells, by the monoclonal antibody, ipilimumab, improved overall survival in patients with metastatic melanoma treated in combination with dacarbazine (Robert et al., 2011a). Moreover, expansion of tumor-infiltrating lymphocytes ex vivo and adoptive T-cell transfer immunotherapy led to regression of metastatic melanoma and durable responses in patients (Dudley et al., 2002; Rosenberg et al., 2011).

\subsubsection{Fibroblasts}

Fibroblasts account for the majority of stromal cells within solid tumors and are the principal source of ECM constituents (Chang et al., 2002). Fibroblasts in tumors are termed as cancer-associated fibroblasts (CAFs).

Tumors have been described as wounds that do not heal (Dvorak, 1986). Indeed, it has been observed that tumor-associated fibroblasts are biologically similar to the ones involved in wound healing or fibrosis (Ryan et al., 1973; Schor et al., 1988). Fibroblasts involved in these processes produce more ECM proteins and proliferate faster than the normal counterparts from healthy tissues (Castor et al., 1979; Muller and Rodemann, 1991). Fibroblasts with these properties are referred as "activated fibroblasts" or "myofibroblasts", due to their characteristic expression of a-smooth muscle actin (a-SMA) (Gabbiani, 2003; Ronnov-Jessen et al., 1996). Fibroblasts can be activated by various stimuli, such as transforming growth factor- $\beta$ (TGF $\beta$ ), epidermal growth factor (EGF), platelet-derived growth factor (PDGF) and fibroblast growth factor 2 (FGF2) (Zeisberg et al., 2000).

CAFs play an important role in promoting tumor initiation and progression by stimulating angiogenesis and tumor cell growth and invasion (Shimoda et al., 2010). The existence of a large number of CAFs in tumors is often associated with poor prognosis (Maeshima et al., 2002; Surowiak et al., 2006). CAFs produce growth factors, cytokines, chemokines and ECM proteases to stimulate angiogenesis and cancer cell proliferation and invasion. For example, CAFs secrete elevated levels of stromal cell-derived factor 1 (SDF-1; also called CXCL12) that facilitates angiogenesis by recruiting endothelial progenitor cells into the tumor (Orimo et al., 2005). SDF-1 can also interact with the CXCR4 receptor expressed on the surface of cancer cells, thus stimulating tumor cell growth and promoting tumor progression in vivo (Orimo and Weinberg, 2006). TGF $\beta$, another factor produced by CAFs, is a critical mediator of the epithelial-to-mesenchymal transition (EMT); therefore, CAFs might contribute to EMT in nearby cancer cells and promote their invasiveness (Shimoda et al., 2010). Moreover, CAFs facilitate cancer cells to invade ECM and metastasize by releasing ECM-degrading proteases, such as matrix metalloproteinases (MMPs) (Boire et al., 2005; Sternlicht et al., 1999). 
CAFs can maintain the myofibroblastic properties even after several passages in vitro without further signaling from carcinoma cells. How do CAFs acquire and maintain their activated phenotype? There are some controversial results with regard to the presence of somatic genetic alterations in CAFs. It has been reported that stroma microdissected from various human cancers exhibited some genetic alterations, such as chromosomal loss of heterozygosity (LOH) and somatic mutations (Currie et al., 2007; Kurose et al., 2002; Moinfar et al., 2000; Paterson et al., 2003; Tuhkanen et al., 2004; Wernert et al., 2001). Other reports also demonstrated that in the process of tumor development, fibroblasts that have lost p53 activity were clonally selected, leading to a highly proliferative stroma (Hill et al., 2005; Kiaris et al., 2005). In contrast, several genome-wide genetic analyses, including CGH and SNP arrays, were not able to detect any genetic alterations in the myofibroblasts isolated from various human cancers (Qiu et al., 2008; Walter et al., 2008). Other studies have suggested that epigenetic modifications within the genome of CAFs, such as DNA methylation, might be the reason (Hu et al., 2005; Jiang et al., 2008). Further studies are required to clarify these issues.

\subsubsection{Cancer stem/initiating cells}

Although cancer can originate from a single transformed cell, not all the cancer cells within a tumor are identical; in other words, cancer cells become heterogeneous during the somatic evolution process, reflected by distinct tumor regions with different histopathological characteristics and various degrees of tumor hallmark capacities. Moreover, mounting evidence indicates that tumor cells are also heterogeneous with regard to the capability to generate new tumors (Cho and Clarke, 2008; Lobo et al., 2007). Multiple studies showed that distinct subpopulations of cancer cells could be sorted from primary tumor samples based on their cell-surface antigen profiles. When different subpopulations of cells were injected into immune-deficient mice, only a subset of cells was able to propagate tumor growth, whereas other cells were unable to induce tumor regeneration (Lobo et al., 2007). This population of cancer cells has also been demonstrated to have the ability of self-renewal and differentiation, two hallmark characteristics of stem cells (Clarke et al., 2006). In addition, these cells also expresses some markers of normal stem cells (Al-Hajj et al., 2003); hence, these cells are termed as 'cancer stem cells' (CSCs; also referred as cancer initiating cells or tumorigenic cancer cells).

CSCs were initially identified in leukemia (Bonnet and Dick, 1997; Lapidot et al., 1994) and later in solid tumors that include cancers of breast, brain, pancreas, head and neck, and colon (Al-Hajj et al., 2003; Dalerba et al., 2007; Li et al., 2007; O'Brien et al., 2007; Prince et al., 2007; Ricci-Vitiani et al., 2007; Singh et al., 2004). Studies of leukemia stem cells suggest that, CSCs may arise from normal stem cells that acquire oncogenic mutations and undergo transformation (Fialkow, 1990; Lapidot et al., 1994; Lobo et al., 2007), or progenitor cells that gain the ability to self-renew through oncogenic transformation (Cozzio et al., 2003; Krivtsov et al., 2006; So et al., 2004). However, recent observations suggest that CSCs may also be derived from non-CSCs via the EMT process (Mani et al., 2008; Morel et al., 2008; Singh and Settleman, 2010), which plays an important role in morphogenesis and in promoting tumor cell motility and invasiveness (Hugo et al., 2007; Thiery, 2003). This model indicates that whereas CSCs can differentiate into non-CSCs; non-CSCs may also be reprogrammed and converted to CSCs, suggesting the existence of a dynamic interconversion between CSCs and non-CSCs that is controlled by the tumor microenvironment (Gupta et al., 2009). Such 
plasticity of CSC state is absent in the conventional depiction of normal stem cells, and has changed the perception of CSCs biology.

With regard to the frequency of CSC representation in tumors, there are conflicting results and ongoing controversies. Initially, CSCs were described to exist only as small subpopulations within tumors (Bonnet and Dick, 1997; Lapidot et al., 1994); moreover, since normal stem cells are usually rare, it was assumed that CSCs should also be rare. However, recent studies on human melanoma suggested that as many as a quarter of the cancer cells could be CSCs (Kelly et al., 2007; Quintana et al., 2008). This disparity on the frequency of CSCs reported were partially attributed to the experimental xenograft conditions in which the ability of human tumor cells to seed and grow in a mouse tissue may vary (Quintana et al., 2008). The plasticity of CSCs state may also in part account for the differences of CSCs representation. The balance of the interconversion between CSCs and non-CSCs could be shifted in one direction or another in response to microenvironmental signals (Santisteban et al., 2009; Till et al., 1964). It is suggested that the proportion of CSCs may differ between tumor types, dependent on stromal microenvironment and somatic mutations within tumors as well as tumor progression stage (Gupta et al., 2009).

The existence of CSCs has attracted growing attention as CSCs may provide explanations for some puzzled clinical problems and imply novel cancer therapies (Clevers, 2011). CSCs have been shown to be more resistant to a variety of conventional radio/chemotherapies than non-CSCs (Chiu et al., 2010; Diehn et al., 2009; Li et al., 2008). Together with their ability to regenerate tumor and to colonize distant organs (Hermann et al., 2007), CSCs are proposed to be responsible for cancer recurrence following chemotherapy or radiation treatment, and for metastases that appear after surgical removal of a primary tumor. In addition, CSCs hypothesis implies that development of novel and more effective treatments that target the 'seeds' of the tumors might be a promising improvement of current therapy regimen. However, the plasticity of CSC phenotype implies that eliminating CSCs alone may not effectively cure tumors as they can be regenerated from non-CSCs, calling for dual targeting therapeutic regimens (Gupta et al., 2009). Moreover, there are controversies about the CSCs model and the experimental strategy employed to define the existence of CSCs. There are rising concerns about the xenograft assay, a typical experimental strategy in the CSC research, in which sorted cancer cells are xenotransplanted into immunodeficient mice. However, this method could induce cellular stress of the isolated cancer cells; moreover, the species barrier and the transplantation procedure within this approach could complicate the process of CSC identification (Clevers, 2011). It will be of importance to devise new strategies to detect functional presence of CSCs within a tumor.

\subsection{Angiogenesis}

The growth and progression of tumors rely on blood vessels to acquire oxygen and nutrients and to remove metabolic wastes (Papetti and Herman, 2002). During the early stage of tumor development, once the size of a tumor mass reaches the diffusion limit for oxygen and nutrients, it may stay in a dormancy state with a steady rate of cell proliferation and death (Fukumura and Jain, 2007). Some human tumors can remain dormant for a number of years. However, the steady state may be disturbed as oxygen-deprived tumor cells release angiogenic factors that trigger the 'angiogenic switch' and initiate new blood vessel formation from nearby existing ones (a process called angiogenesis) (Hanahan and 
Folkman, 1996; Hanahan and Weinberg, 2000). Angiogenesis expands the tumor vascular network, enabling malignant cell proliferation and metastasis. Therefore, angiogenesis is a rate-limiting step in tumor development and progression.

Angiogenesis is controlled by a fine-tuned equilibrium between angiogenic and angiostatic factors (Baeriswyl and Christofori, 2009; Bergers and Benjamin, 2003; Carmeliet and Jain, 2000). Under normal physiological conditions, this balance is tightly regulated, so that the 'angiogenic switch' is 'on' only when needed and otherwise remains 'off'. Moreover, the newly formed vessels rapidly mature and become quiescent. By contrast, in tumors, the balance between positive and negative controls is disrupted due to an overproduction of pro-angiogenic factors. Consequently, new blood vessels are constantly produced in tumors. To date, more than two dozen pro-angiogenic factors and similar number of anti-angiogenic factors have been identified. Key pro-angiogenic molecules include vascular endothelial growth factor (VEGF), angiopoietin 1 (Ang1), platelet-derived growth factor (PDGF), placenta growth factor (PlGF), fibroblast growth factor 2 (FGF2), hepatocyte growth factor (HGF), among others (Adini et al., 2002; Papapetropoulos et al., 1999). Important angiogenic inhibitors include thrombospondin, angiostatin, endostatin, canstatin and tumstatin (Folkman, 2006; Kazerounian et al., 2008; Nyberg et al., 2005).

VEGF signaling pathway is the most prominent and best characterized pro-angiogenic pathway (Ferrara et al., 2003). The VEGF family includes VEGF-A, B, C, D, and PlGF (Ferrara, 2002; Hicklin and Ellis, 2005). VEGF-A (also called VEGF) is the major regulator of tumor angiogenesis. There are several isoforms of VEGF-A, with 121, 165, 189 and 206 amino acids, which are generated by alternative splicing (Houck et al., 1991; Tischer et al., 1991). VEGF-A mainly binds to VEGF receptor 2 (VEGFR-2) and triggers various downstream signaling pathways to up-regulate genes that stimulate endothelial cell proliferation, migration and survival and increase vascular permeability (Dvorak, 2002; Shibuya and Claesson-Welsh, 2006). VEGF is expressed at elevated levels in most types of human cancer. This can be caused by diverse genetic and epigenetic factors (Kerbel and Folkman, 2002; Kerbel, 2008). Hypoxia, a hallmark of tumor microenvironment, is an important inducer of VEGF through the hypoxia-inducible factor (HIF) 1a and 2a (Semenza, 2003). In addition, inflammatory cytokines, growth factors and chemokines can also induce VEGF expression. Other genetic causes include activation of oncogenes, such as mutant ras (Rak et al., 1995), or inactivation of tumor-suppressor genes, such as the von Hippel-Lindau (VHL) tumor suppressor (Patard et al., 2009).

In addition to VEGF, there are other important signaling pathways that regulate angiogenesis. Endothelial cell-associated delta-like ligand (Dll) 4-notch signaling pathway acts as negative feedback mechanism of VEGF signaling to prevent excessive tumor angiogenesis (Lobov et al., 2007; Ridgway et al., 2006). HGF/c-Met signaling can induce VEGF and VEGFR expression and also promote angiogenic proliferation and survival (You and McDonald, 2008). FGF2 signaling can stimulate angiogenesis independent of VEGF (Beenken and Mohammadi, 2009). PDGF-B signaling is important for the recruitment of pericytes to nascent blood vessels and stabilization/maturation of the vasculature (Lindahl et al., 1997). The angiopoietins (Ang-1, 2), interacting with the Tie2 receptor, act in cooperation with VEGF to promote angiogenesis and stabilize and mature new vasculature (Augustin et al., 2009). PlGF, signaling through VEGFR1, is another growth factor that induces endothelial cell proliferation, migration and survival (Fischer et al., 2007). 
Moreover, endothelial progenitor cells can also be recruited and contribute to the formation of new blood vessels.

Due to the imbalanced expression of pro- and anti-angiogenic factors (Jain, 2005), tumor vasculature is often abnormal in architecture and function (Baluk et al., 2005; Fukumura and Jain, 2007). In contrast to the well-organized normal vascular tree, tumor blood vessels are highly variable in size, shape, and branching pattern. They are tortuous, dilated, irregularly shaped, and lack the normal hierarchy of arterioles, capillaries and venules. The structure of vessel wall is also defective, with large inter-endothelial junctions and loose perivascular cells attachment (McDonald and Choyke, 2003; Morikawa et al., 2002). Hence, tumor blood vessels are often leaky and hemorrhagic. Vascular permeability in tumor is generally higher than that in normal tissues, leading to increased interstitial fluid pressure. Also, blood flow in tumor vessels is irregular, slower, oscillating, and sometimes can even reverse the direction. Therefore, in spite of the production of excess blood vessels, the perfusion efficiency in tumor is still low. The aberrant tumor vasculature fails to meet the demand of growing tumor for nutrients and oxygen, as well as to adequately remove waste products. Chronically, the tumor microenvironment becomes hypoxic and acidic (Fukumura and Jain, 2007). As stated in more detail in the following sections, hypoxia and acidosis are selection forces for cancer cell somatic evolution and also significantly affect radiation sensitivity and chemotherapeutic efficacy.

As angiogenesis plays a critical role in tumor growth and progression, anti-angiogenesis therapy has been developed aiming to halt tumor growth by depriving cancer cells of the blood supply (Ferrara and Kerbel, 2005). Most of the angiogenesis inhibitors target the VEGF signaling pathway, including antibodies directly against VEGF and small molecules inhibiting its receptors. These anti-angiogenic agents have provided clinical benefits in patients with various types of cancers. Detailed discussion on anti-angiogenesis therapy is presented in the Section 3.1.

\subsection{Hypoxia}

The defective architecture and functionality of tumor blood vessels results in the occurrence of hypoxic regions in solid tumors (Fukumura and Jain, 2007; Gatenby and Gillies, 2004). Hypoxia is further exacerbated by the uncontrolled and rapid proliferation of tumor cells. These cancerous cells consume large amounts of oxygen and nutrients during their rapid divisions, further dictating the need for ample blood supply. As the oxygen diffusion limit is reached and the partial pressure of oxygen, $\mathrm{pO}_{2}$, drops towards zero, cells must adapt and rely upon alternative means to acquire energy in this hypoxic microenvironment (Bertout et al., 2008; Cairns et al., 2006; Fukumura and Jain, 2007; Gatenby and Gillies, 2004, 2007). A common adaptation strategy is the dependence upon glycolytic metabolism, coined the 'Warburg Effect' (Gatenby and Gillies, 2004; Warburg, 1956). In cancer cells, a large portion of glucose is utilized through glycolysis, by which each glucose molecule is converted to two ATP and two lactic acid molecules. In contrast, normal cells obtain the majority of their ATP through oxidative phosphorylation, which results in the release of 36 ATP from one glucose molecule (Gatenby and Gillies, 2004; Vander Heiden et al., 2009). While less efficient in ATP production, glycolysis generates intermediate molecules as substrates for nucleotide, lipid and amino acid biosynthesis, which is crucial for rapidly dividing cancer cells (Vander Heiden et al., 2009). It is proposed that the acquisition of glycolytic metabolism offers a 
selective advantage for cancerous cells, allowing them to adopt a more malignant phenotype (Gatenby and Gillies, 2004; Vander Heiden et al., 2009).

In addition to the noted alteration in the mode of energy acquisition, hypoxia is also known to regulate gene expression of cells. To proliferate and thrive in a hypoxic environment, cancer cells must modulate numerous cellular pathways. For example, pathways that initiate the acquisition of a motile and invasive phenotype, such as the c-Met pathway (Eckerich et al., 2007), are activated to facilitate cancer cells to leave the primary, hypoxic tumor (Hanahan and Weinberg, 2011). It has been discovered that hypoxia-inducible factor 1 (HIF-1) is a master regulator of many of the pathways that allow cancer cells to thrive in a hypoxic environment (Bertout et al., 2008; Semenza, 2007a, b). HIF-1 is reported to control the transcription of many genes, including those needed for maintaining cell viability, vascularization, glucose uptake, and metabolic reprogramming. HIFs are known to regulate pro-angiogenic and pro-glycolytic pathways. In animal models, HIF-1 overexpression has been associated with invasion, tumor growth and increased vascularization. Furthermore, HIF-1a overexpression has been correlated with an increase in patient mortality (Rankin and Giaccia, 2008; Semenza, 2007a). HIF proteins have also recently been attributed to the survival and self-renewal of cancer stem cells (CSCs), which are involved in cancer cell propagation and the development of aggressive and metastatic phenotypes (Heddleston et al., 2010; Wang et al., 2011). The Notch and Oct4 pathways, responsible for maintaining the stem cell phenotype, have been reported to be under the regulatory control of HIF protein. Due to the immense involvement of HIF-1 in transcriptional regulation of genes that promote survival and progression of cancer cells in a hypoxic environment, it serves as a target of anti-cancer therapies (Semenza, 2007a; Tennant et al., 2010).

Another effect of hypoxia lies in the resistance of cancer cells to chemotherapy and radiation treatment (Cairns et al., 2006; Gatenby and Gillies, 2004). Oxygen is known to increase the effectiveness of radiation therapy as it is a potent radiosensitizer. In turn, hypoxia can invoke a resistance of cancer cells to radiation and some forms of chemotherapy (Cairns et al., 2006). This hypoxia-induced resistance can be attributed, among many factors, to an inability in chemotherapy and radiation to induce cell cycle arrest, DNA breaks, and apoptosis (Wilson and Hay, 2011). Furthermore, hypoxia can up-regulate the expression of genes known to cause resistance to chemotherapeutics, such as multidrug resistance gene (MDR1), and downregulate the expression of apoptosis regulating genes (Bertout et al., 2008).

\subsection{Acidosis}

As discussed above, cancer cells develop a modified form of energy metabolism in which glucose incorporated by the tumor is mainly converted into ATP and lactic acid through glycolysis even in the presence of oxygen (Gatenby and Gillies, 2004; Vander Heiden et al., 2009; Warburg, 1956). In addition, it is believed this switch to a glycolytic phenotype, although inefficient in ATP production, is overall beneficial for rapidly dividing cancer cells (Cairns et al., 2011; Vander Heiden et al., 2009). However, the glycolytic metabolism directly results in the development of acidic interstitial $\mathrm{pH}$ in the tumor microenvironment, another stress that cancer cells must evolve to evade.

Acidosis is another defining hallmark of the tumor microenvironment. Interstitial accumulation of hydrogen ions is due to the production of lactic acid from glycolysis and 
other proton sources from, such as, ATP hydrolysis and carbonic acid (Gatenby and Gillies, 2004; Helmlinger et al., 2002; Yamagata et al., 1998). Whereas the intracellular pH of cancer cells is kept neutral, an extracellular $\mathrm{pH}$ of 6.5-6.8 is often observed in the interstitial space of tumors (Griffiths et al., 2001). To maintain a relatively neutral intracellular $\mathrm{pH}$, cancer cells utilize an array of acid-base transporters, such as sodium/hydrogen exchangers, vacuolartype $\mathrm{H}^{+}$-ATPases, and monocarboxylate transporters, to extrude the excess protons from cancer cells (Izumi et al., 2003; Webb et al., 2011).

Just as the ability for tumor cells to adapt to a hypoxic microenvironment offers a distinct evolutionary advantage towards an aggressive phenotype, so does the ability for cancer cells to survive in an acidic microenvironment. Upon exposure to the low extracellular $\mathrm{pH}$ found in and around solid tumors, many of the normal, non-cancerous cells in the surrounding tissue undergo cell death, often attributed to p53-dependent pathways. Cancer cells that have evolved to be immune to this notable acidosis are often left highly invasive and aggressive (Gatenby and Gillies, 2004). Acidosis is also known to contribute towards tumor cell invasion through the release of proteolytic enzymes that degrade extracellular matrix. Hypoxia and acidosis have been reported to increase the secretion and activity of matrix metalloproteinases (MMPs) and other matrix-degrading enzymes (Bourguignon et al., 2004; Johnson et al., 2000; Ridgway et al., 2005).

Acidosis also plays a role in the cytotoxic effectiveness of radiation and chemotherapy. Microenvironmental acidosis has been shown to invoke a resistance to radiation-induced apoptosis of cancer cells (Hunter et al., 2006). Acidic extracellular $\mathrm{pH}$ can also modulate the uptake of chemotherapeutic drugs, especially the weak acid and weak base drugs (Cairns et al., 2006; Gerweck et al., 2006). In the acidic tumor microenvironment, weak base drugs, such as doxorubicin, exist in a highly charged state. In turn, the uptake of these drugs across the plasma membrane is inhibited, thereby reducing the ability of the chemotherapeutic drugs to reach their cytotoxic target. In contrast, weak acid drugs, such as chlorambucil, exist in a non-charged state at acidic $\mathrm{pH}$ and, therefore, have increased cell permeability.

\subsection{Somatic evolution and cancer cell metastasis}

As normal cells are transformed to pre-malignant tumor cells and further towards malignant and metastatic tumors, the process of somatic evolution is actively used (Gatenby and Gillies, 2004). Cancer cells arise through gene mutations. Oncogenes with a dominant gain of function arise, while tumor suppressor genes become inactivated through a loss of function. As a result of somatic evolution, some of the traits that promote the cancerous phenotype include the evasion of apoptosis, limitless replicative potential, sustained angiogenesis, the ability for invasion and metastasis, and deregulated energy metabolism (Hanahan and Weinberg, 2011).

Carcinogenesis and Darwinian dynamics draw an analogy as new phenotypes are generated through heritable genetic changes and subsequent selection for the fittest by the environment (Gatenby and Gillies, 2004, 2008). It has been proposed that hypoxia and acidosis both apply extreme constraints and act as selection forces for progressive tumor cells. Cancer cells that have gained immunity to these conditions, such as through the Warburg effect and other adaptations, display a distinct advantage over neighboring normal cells. Cancer cells that are able to thrive in the harsh environment are highly aggressive with 
a resistant phenotype. Communication between tumor cells and the microenvironment is crucial for the cells to take advantage of the changes in the microenvironment and develop a malignant phenotype (Gatenby and Gillies, 2004; Lorusso and Ruegg, 2008).

There are many mechanisms by which cancer cell somatic evolution is driven by the microenvironmental selection forces. Primarily, various pathways crucial for cancer cell survival under the hypoxic and acidotic conditions are activated, such as those that promote a downregulation of apoptosis, a switch to glycolytic metabolism, and an upregulation of HIFs (Gatenby and Gillies, 2004; Heddleston et al., 2010; Vander Heiden et al., 2009; Wilson and Hay, 2011). Cancer cells resistant to acidosis and hypoxia often acquire p53 mutations. As p53 is important for apoptosis, cells that have a mutation in this gene exhibit an advantage as they are often immune to the cytotoxic microenvironment (Bertout et al., 2008). In addition, many tumor cells develop a very active sodium/hydrogen exchange system and other proton transport mechanisms, which facilitate the extrusion of excess protons (Izumi et al., 2003; Webb et al., 2011). The resulting cytoplasmic alkalinization is thought to be crucial for cell reproduction in the acidic environment. Therefore, the hallmarks of the tumor microenvironment, such as hypoxia and acidosis, actively function as selection forces to shape cancer cell phenotypes during the somatic evolution process (Gatenby and Gillies, 2004; Webb et al., 2011).

The ability to acquire a metastatic phenotype via somatic evolution is one of the most devastating properties of cancer cells, and is directly correlated with an increase in patient morbidity and mortality (Fidler, 2002; Steeg, 2006). Current cancer therapy approaches, such as surgery, radiation and chemotherapy, can be effective in controlling primary, localized tumor. However, these modes of treatment are severely limited in retarding the spread of cancer as they do little to impair metastasis. It is therefore evident that the development of novel means of combating tumor cell metastasis is crucial towards the eradication and control of this disease.

The general steps of tumor metastasis involve the initial acquisition of motility and invasiveness, intravasation, transit in the blood or lymph, extravasation and finally arrest and growth at a new site (Fidler, 2002; Sahai, 2007; Steeg, 2006). The tumor microenvironment plays a large role in the ability of cancer cells to acquire a metastatic phenotype. As previously touched upon, two of the defining characteristics of the tumor microenvironment, hypoxia and acidosis, both actively select for more invasive and metastatic phenotypes (Chang et al., 2011; Gatenby et al., 2006; Gatenby and Gillies, 2004). It is also reported that inflammatory cells, fibroblasts and other stromal cells in the tumor microenvironment can contribute to the progression of a tumor towards a more malignant, metastatic phenotype (Joyce and Pollard, 2009; Lorusso and Ruegg, 2008).

\section{Tumor microenvironments as targets for cancer prevention and therapy}

Cellular components and molecular pathways associated with tumor microenvironments have been exploited as targets for cancer prevention and therapy. In fact, combination therapy targeting both cancer cells and other related cells and pathways, such as vascular cells and immune cells, can lead to more effective cancer treatment (Cairns et al., 2006; Ferrara and Kerbel, 2005; Luo et al., 2009). Therapeutic approaches modulating angiogenesis, inflammation, and hypoxia and acidosis pathways will be discussed below. 


\subsection{Anti-angiogenesis cancer therapy}

As described in the 'angiogenesis' session, tumors rely on angiogenesis to grow and disseminate. Therefore, it has been proposed that tumor growth can be inhibited by starving tumor cells through angiogenesis blockade (Folkman, 1971). Since VEGF is a major regulator of tumor angiogenesis, a number of agents targeting VEGF and its receptors have been developed and several have been approved by the Food and Drug Administration (FDA) for clinical applications. Among them, bevacizumab (Avastin, Genentech/Roche) is a humanized monoclonal antibody directly against VEGF (Ferrara et al., 2004; Presta et al., 1997), and sunitinib (Sutent, Pfizer) and sorafenib (Nexavar, Bayer) are small molecule inhibitors that target multiple receptor tyrosine kinases (RTK), including VEGF receptors and PDGF receptors (Faivre et al., 2007; Kupsch et al., 2005; O'Farrell et al., 2003).

Bevacizumab was approved by the FDA in 2004 on the basis of the survival benefit observed in a randomized phase III clinical trial, in which bevacizumab was administrated in combination with chemotherapy in patients with previously untreated metastatic colorectal cancer (Hurwitz et al., 2004). The clinical benefit of bevacizumab was also evaluated in other cancer types. The combination of bevacizumab with paclitaxel and carboplatin in patients with previously untreated nonsquamous non-small-cell lung cancer (NSCLC) improved primary endpoint of overall survival (OS) (Sandler et al., 2006). Moreover, the combined regimen of bevacizumab with 5-fluorouracil, leucovorin, and oxaliplatin (FOLFOX) were used to treat patients with previously treated metastatic colorectal cancers and prolonged progression-free survival (PFS) and OS (Giantonio et al., 2007). More recently, bevacizumab monotherapy was approved as a second-line therapy for glioblastoma multiforme (GBM) (Cohen et al., 2009). Some severe adverse effects of bevacizumab therapy, including gastrointestinal perforation and arterial thromboembolic complications, were observed in a small percentage of patients. Other side effects such as hypertension were also noticed (Eskens and Verweij, 2006; Verheul and Pinedo, 2007). Notably, in addition to the oncologic application, VEGF inhibitors are also used to treat the neovascular (wet) age-related macular degeneration (AMD), as VEGF has been demonstrated to be a mediator of ischemia-induced intraocular neovascularization (Chen et al., 1999; Ferrara et al., 2006; Gragoudas et al., 2004; $\mathrm{Ng}$ et al., 2006; Rosenfeld et al., 2006).

Sunitinib and sorafenib are RTK inhibitors that inhibit the tyrosine phosphorylation of VEGFRs, PDGFRs, c-kit, and Flt-3 (Fabian et al., 2005; Smith et al., 2004). Sunitinib has been reported to prolong the time to progression in imatinib-refractory gastrointestinal stromal tumors (Goodman et al., 2007). Sunitinib was also approved by FDA for the treatment of metastatic renal cell carcinoma (Motzer et al., 2009; Motzer et al., 2006). Sorafenib has been shown to increase PFS in patients with metastatic renal cell carcinoma (Escudier et al., 2007). In addition, sorafenib was approved for treating hepatocellular carcinomas (Lang, 2008; Llovet et al., 2008). Pazopanib, another RTKI, was approved for the treatment of metastatic renal cell carcinoma (Sternberg et al., 2010). Moreover, there are other anti-angiogenic agents under investigation that target other signaling molecules involved in angiogenesis, such as antibodies against angiopoietin-2 and PIGF which have been shown to delay tumor growth in preclinical models (Fischer et al., 2007; Oliner et al., 2004).

There were also some clinical trials with angiogenesis inhibitors that did not show significant clinical benefits. For instance, the combination of bevacizumab with gemcitabine didn't show improved PFS or OS in patients with chemotherapy-naïve advanced pancreatic 
cancer (Kindler et al., 2010). An earlier phase III trial of bevacizumab combined with gemcitabine and erlotinib for the same type of cancer increased PFS but didn't improve primary endpoint of OS either (Van Cutsem et al., 2009). PFS, although an indicator of the efficacy of drugs, is a poor surrogate for OS, as PFS benefits are not always translated into OS benefits (Wilkerson and Fojo, 2009). The controversies about whether to keep the FDA's approval of bevacizumab for metastatic breast cancer provide such an example. In 2008, bevacizumab was approved for treating breast cancer in combination with chemotherapy based on the results from the clinical trial E2100 (Miller et al., 2007). However, the study was only able to show an improved primary endpoint of PFS but not OS. Several subsequent clinical trials showed similar results (Miles et al., 2010; Robert et al., 2011b), which leads to recent recommended withdrawal of bevacizumab by FDA for metastatic breast cancer (Lenzer, 2011).

Another major problem is that, even in those successful trials, the VEGF pathway inhibitors can only generate transitory clinical responses in most patients, with increased survival typically measured in months (Kerbel, 2008). Almost inevitably, temporary tumor shrinkage or stasis was followed by tumor relapse and progression. The modest responses to the antiangiogenic agents are partly due to the existence of resistance to the therapeutics (Bergers and Hanahan, 2008). Tumor cells and the stroma they reside in can adapt to the presence of angiogenesis inhibitors by acquiring means to evade angiogenesis blockade and sustain blood vessel and tumor growth. One important compensatory response is that, when the VEGF signaling pathway is inhibited, tumor may activate or up-regulate the expression of alternative pro-angiogenic factors, such as FGF2, PlGF, and PDGF pathways (Fernando et al., 2008); or in other cases, there are pre-existing redundant pro-angiogenic factors in the treated tumors (Bergers and Hanahan, 2008).

Furthermore, a growing list of studies indicates that anti-angiogenic therapies may even lead to increased tumor invasiveness and metastasis (Ebos et al., 2009; Paez-Ribes et al., 2009). Questions and concerns have been raised about the efficacy and safety of antiangiogenic agents in blocking different stages of tumor progression. Potential mechanisms of the increased metastasis may involve both tumor-dependent and hostmediated responses (Ebos and Kerbel, 2011), such as increased expression of pro-metastatic proteins (Pennacchietti et al., 2003; Rofstad and Halsor, 2002), induction of tumor cell EMT (Higgins et al., 2007), and pericyte dysfunction (Bergers et al., 2003), among others. Perhaps the most prevailing proposition is that inhibition of angiogenesis could elicit an elevated level of tumor hypoxia, which selects for cancer cell populations that are able to grow in low oxygen environments and promote tumor invasion and metastasis (Rapisarda and Melillo, 2009). Studies have demonstrated that hypoxia-induced mechanisms, such as the upregulation of c-Met and interleukin 8 (Pennacchietti et al., 2003; Rofstad and Halsor, 2002; Steeg, 2003), can promote cancer cells to disseminate to distant locations (Kienast et al., 2010).

As a breakthrough in cancer treatment, anti-angiogenesis therapies have provided survival benefits in certain cancer types and represent an important complement to the traditional chemotherapy strategies. However, there are ongoing challenges, such as the lack of lasting benefits for the majority of patients and an emerging, though still controversial, possibility that increased tumor invasion and metastasis might in some instances be induced by antiangiogenesis therapy. It will be of importance to understand the molecular basis of the 
treatment limitations and to formulate improved strategies to overcome them. For example, combining anti-angiogenic therapy with anti-hypoxia agents or anti-metastatic agents might help overcome the metastatic phenotype induced by increased tumor hypoxia.

\subsection{Anti-inflammation in cancer chemoprevention and therapy}

Numerous studies show that inflammation plays an important role in cancer initiation, progression and metastasis. As described in the Section 2, infiltrating inflammatory cells such as macrophages, mast cells and neutrophils produce reactive oxygen and nitrogen species, growth factors, cytokines, chemokines, proteases and other bioactive factors in the tumor microenvironment (de Visser et al., 2006; Grivennikov et al., 2010). These bioactive factors can induce DNA mutagenesis, inhibit DNA repair enzymes, stimulate cancer cell proliferation, degrade extracellular matrix, and promote cancer cell invasion and metastasis. On the other hand, certain types of infiltrating immune cells, such as cytotoxic $\mathrm{T}$ cells and natural killer cells, can inhibit tumor progression.

Chronic inflammation is closely associated with the development of some types of cancers. For instance, patients with inflammatory bowel disease or ulcerative colitis have an increased risk of developing colorectal cancer (Xie and Itzkowitz, 2008). Chronic Helicobacter pylori infection and ulcers are associated with gastric cancer and mucosa-associated lymphoid tissue lymphoma. Infection with hepatitis B virus increases the risk of developing liver cancer (Pages et al., 2010). Furthermore, epidemiological studies indicate that the use of aspirin and other nonsteroidal anti-inflammatory drugs is associated with a reduced cancer incidence. These widely documented observations provide the rationale to assess antiinflammatory agents in cancer chemoprevention and therapy (Kashfi, 2009).

Nonsteroidal anti-inflammatory drugs (NSAIDs) have been extensively evaluated for cancer chemoprevention. Aspirin (acetylsalicylic acid), a prototype NSAID, inhibits the cyclooxygenase (COX) enzymes and suppress the production of prostaglandins and thromboxanes. Aspirin exhibits chemopreventive effects on colon cancer in several randomized trials. A recent study performed a 20-year follow-up of 5 randomized trials to investigate the long-term effects of aspirin (75-300 mg daily) on colorectal cancer incidence and mortality (Rothwell et al., 2010). 391 of 14,033 patients (2.8\%) had colorectal cancer during a median 18.3-year follow-up. Compared to the control group, the incidence of colon cancer, but not rectal cancer, was lower in the aspirin group. Furthermore, the benefit of aspirin increased with the duration of treatment. Allocation to aspirin treatment for 5 years or longer reduced the risk of proximal colon cancer by $\sim 70 \%$ and also decreased the risk of rectal cancer. Moreover, a meta-analysis of 3 randomized controlled trials showed that, in more than 2,000 patients with previously resected colorectal adenomas, the aspirin groups (dose range from 81 to $325 \mathrm{mg}$ per day), in comparison to the placebo groups, had a lower rate of tumor recurrence (Gao et al., 2009). In addition to colorectal cancer, a recent study showed that daily aspirin treatment for 5 years or longer reduced the mortality from several common types of solid cancers (Rothwell et al., 2011). However, not all studies supported the protective role of aspirin in cancer prevention. In the Woman's Health Study, a low dose $(100 \mathrm{mg})$ of aspirin every other day for an average 10 years of treatment did not reduce the risk of total, breast, colorectal, and other cancers (Cook et al., 2005). The major adverse effects of aspirin treatment are gastrointestinal bleeding and ulceration.

In addition to aspirin, COX-2 specific inhibitors have been tested as cancer chemopreventive agents. There are two COX genes in the cell: COX-1 is constitutively expressed in many 
tissues and COX-2 is induced upon inflammation and other stimuli (Botting, 2010). Earlier clinical studies showed that the COX-2 inhibitor, celecoxib (400 mg twice per day for 6 month), resulted in approximately $30 \%$ reduction in polyp number and size in familial adenomatous polyposis (FAP) patients (Steinbach et al., 2000). However, studies found that prolonged use of COX-2 inhibitors increased the risk of cardiovascular events in a doserelated manner (Baron et al., 2008; Solomon et al., 2005; Solomon et al., 2006). These findings led to the discontinuation of the clinical trials and the withdrawal of the drugs from the market. Clearly, drugs with improved safety profiles are required for the long-term use in cancer chemoprevention. In this respect, the "old" NSAID, aspirin, has been widely used to prevent cardiovascular diseases and, therefore, has a favorable cardiovascular profile.

Inflammatory chemokines and their receptors have also been exploited as targets for cancer therapy. Chemokines are a family of chemotactic cytokines that bind to cognate $G$ proteincoupled receptors. Forty-seven chemokine members have been identified and are divided into 4 subfamilies: the CC subfamily, the CXC subfamily, the CX3C subfamily, and the XC subfamily. The chemokine receptors are comprised of the CCR subfamily, the CXCR subfamily, CX3CR1, and XCR1 (Lazennec and Richmond, 2010). In the tumor microenvironment, various chemokines are produced by cancer cells, inflammatory cells, fibroblasts, and endothelial cells. Chemokines can stimulate cancer cell growth and metastasis, recruit inflammatory cells, and promote tumor angiogenesis.

Stromal cell-derived factor-1 (SDF-1, also named CXCL12) and its receptor CXCR4 play important roles in the mobilization and homing of hematopoietic stem cells and the metastasis of cancer cells. AMD3100 (plerixafor), developed by Genzyme, is a small molecule that antagonizes the binding of CXCL12 to its receptor CXCR4, and was recently approved by FDA for stem cell mobilization in non-Hodgkin's lymphoma and multiple myeloma patients (Pusic and DiPersio, 2010). Clinical trials demonstrated that AMD3100 (plerixafor), together with G-CSF, significantly increased the mobilization of hematopoietic stem cells for autologous stem cell transplantation in patients with multiple myeloma and non-Hodgkin's lymphoma (DiPersio et al., 2009a; DiPersio et al., 2009b). AMD3100 (plerixafor) can also be used as a chemosensitizing agent. Studies showed that AMD3100 (plerixafor) impeded the interaction between leukemia cells and the bone marrow microenvironment, mobilized cancer cells into peripheral blood, and increased the sensitivity of multiple myeloma cells and acute myeloid leukemia cells to chemotherapeutic drugs (Azab et al., 2009; Nervi et al., 2009). Furthermore, CXCL12/CXCR4 inhibitors have therapeutic effects on other non-hematological cancers. In pre-clinical models, blockade of CXCR4 has been shown to inhibit the migration and metastasis of melanoma cells, oral squamous cell carcinoma cells, and gastric cancer cells (Kim et al., 2010; Uchida et al., 2011; Zhao et al., 2011). CXCR4 inhibitors could also chemosensitize and suppress the growth of pancreatic and ovarian cancer cells (Righi et al., 2011; Singh et al., 2010). Besides CXCL12/CXCR4, inhibitors for other chemokines/receptors, such as CCL2 and CCR4, are also undergoing clinical development for the treatment of leukemia and solid tumors (Lazennec and Richmond, 2010).

\subsection{Molecular targeting of hypoxia pathways}

As described in the Section 2, hypoxia inhibits the tumor killing effects of radiation and also regulates cancer cell apoptosis, invasiveness and metabolism (Cairns et al., 2006; Gatenby 
and Gillies, 2004). Hypoxia-inducible factors (HIFs) are master regulators of cell hypoxia responses and control the expression of numerous genes involved in angiogenesis, glycolytic metabolism, glucose transport, erythropoiesis, and other processes (Semenza, 2007b). Increased expression of HIFs is correlated with a worse prognosis in many types of cancers. Thus, HIFs have been proposed as a potential target for cancer therapy. Inhibitors of the HIF pathway have been developed and tested in preclinical models and/or clinical trials (Semenza, 2007a).

PX-478, a HIF-1a inhibitor, showed remarkable antitumor activity in human cancer xenograft models (Welsh et al., 2004), and also enhanced radiosensitivity of human pancreatic cancer xenografts (Schwartz et al., 2009). It has been shown that the degradation of HIF-1a can be induced through inhibiting the chaperone protein HSP90 (Isaacs et al., 2002). The HSP90 inhibitor, 17-AAG (Tanaspimycin), exhibited anti-tumor activities in multiple cancer cell models. A recent phase II clinical trial showed that 17-AAG (Tanaspimycin) plus trastuzumab had significant anti-cancer activity in HER2 ${ }^{+}$breast cancer patients previously progressing on trastuzumab (Modi et al., 2011). It should, however, be noted that HIF-1a degradation is only one of the effects of HSP90 inhibitors as HSP90 is required for preventing the degradation of many other proteins.

As a response and adaptation to hypoxia in the tumor microenvironment, cancer cells rely substantially on glycolysis for ATP production. It was discovered by Otto Warburg decades ago that cancer cells preferentially utilize glycolytic metabolism even under aerobic conditions (known as 'Warburg effect') (Warburg, 1956). Since glycolysis only generates 2 ATP molecules per glucose, tumor cells evolve a compensatory mechanism by up-regulating the level of glucose transporters and significantly increasing glucose uptake.

Genes involved in glycolytic metabolism have been proposed as potential cancer therapeutic targets (Tennant et al., 2010). Studies demonstrate that HIFs directly activate the transcription of glucose transporters (e.g. GLUT1) and several key glycolytic enzymes (Semenza, 2007b). Some oncogenes and tumor suppressors, such as Myc, PI3K, p53 and PTEN, can also regulate the expression of genes important for glycolysis and cell metabolism (Dang et al., 2009; Tennant et al., 2010). A recent chemical screening identified a compound, STF-31, which could inhibit the glucose transporter 1 (GLUT1) and the Warburg effect, induce cell death of renal cell carcinoma and inhibit the growth of tumor xenografts (Chan et al., 2011). Agents have also been developed to target the enzymes in the glycolysis pathway. One such agent is the hexokinase inhibitor, 2-deoxyglucose, which has been shown to have anti-tumor activities in multiple cancer cell models (Loar et al., 2010; Zhang and Aft, 2009). Other potential anti-cancer targets in the glycolysis cascade includes pyruvate kinase, the tumor-specific pyruvate kinase M2 (PKM2) isoform, pyruvate dehydrogenase kinase 1 (PDK1), among others (Tennant et al., 2010; Vander Heiden et al., 2009). Inhibitors of these enzymes, such as TLN-232 and dichloroacetate (DCA), are being evaluated in clinical trials. A recent study showed that DCA had anti-tumor activities in glioblastoma patients (Michelakis et al., 2010).

Furthermore, major regulators of metabolic pathways, such as mTOR (mammalian target of rapamycin) and AMPK (AMP-activated protein kinase), have been employed as important targets for cancer therapy. In particular, the mTOR inhibitors, everolimus and temsirolimus, have been approved by FDA for the treatment of advanced renal cell carcinoma with clinical 
benefits in prolonging progression free survival and overall survival (Kwitkowski et al., 2010; Motzer et al., 2008). Moreover, epidemiological studies indicated that the cancer incidence is lower in diabetic patients treated with the AMPK agonist metformin (Bo et al., 2011). In a short-term prospective clinical trial, metformin treatment reduced colorectal aberrant crypt foci in non-diabetic patients (Hosono et al., 2010). These results indicate that metformin may be a useful agent for cancer prevention and therapy (Gonzalez-Angulo and Meric-Bernstam, 2010; Li, 2011).

In addition to targeting hypoxia-related molecular pathways, hypoxia itself can be utilized for cancer therapy. Bioreductive prodrugs, which are activated in hypoxic environments, have been evaluated as potential anti-cancer agents to selectively kill hypoxic tumor cells. For instance, apaziquone (EO9), a bioreductive prodrug, was used through instillation to treat bladder cancer and significantly reduced the rate of tumor recurrence in the clinical trials (Hendricksen et al., 2009; Jain et al., 2009).

Hypoxia as a hallmark of the tumor microenvironment has also been exploited to develop imaging approaches for cancer diagnosis. A family of nitroimidazole derivatives has been used as chemical tracers to detect hypoxia in tissues. A PET probe, $18 \mathrm{~F}-$ fluoromisonidazole (FMISO), has been applied to detect hypoxic regions in solid tumors and to assess the change of tumor hypoxia status in response to therapy such as anti-angiogenesis treatment (Szeto et al., 2009; Valable et al., 2011). In addition, the up-regulation of hypoxia-responsive glucose transporters in tumor cells has been utilized for $\left[{ }^{18} \mathrm{~F}\right]$ fluorodeoxyglucose positron emission tomography (FDG-PET). As the uptake of glucose is substantially increased in cancer cells, the radioactive $\left[{ }^{18} \mathrm{~F}\right]$ fluorodeoxyglucose tracer is preferentially accumulated in the tumor and can be detected by positron emission tomography (Buerkle and Weber, 2008). FDG-PET has been widely used in the clinic to detect tumors and metastases and assess the response of tumors to therapeutics.

\subsection{Molecular targeting of acidosis-related pathways}

In addition to hypoxia, extracellular acidosis is another major hallmark of the tumor microenvironment. To avoid the harmful accumulation of protons and decrease of intracellular $\mathrm{pH}(\mathrm{pHi})$, cancer cells must use the cellular transporter system to expel excess acids from the cells. Carbonic anhydrases (CA), monocarboxylate transporters (MCT), vacuolar-type $\mathrm{H}^{+}$-ATPase proton pump (V-ATPase), and sodium/hydrogen exchangers (NHE) play important roles in cellular pH regulation (Izumi et al., 2003; Swietach et al., 2010; Webb et al., 2011). Furthermore, recent studies have shown that a family of protonsensing G protein-coupled receptors regulates the behavior of tumor cells, immune cells, and blood vessels (Ludwig et al., 2003; Mogi et al., 2009; Yang et al., 2007). Targeting these $\mathrm{pH}$ regulators may be utilized to kill cancer cells or to augment the effects of other anticancer agents.

Carbonic anhydrase (CA) enzymes catalyze the reversible reaction between carbon dioxide and bicarbonate: $\mathrm{CO}_{2}+\mathrm{H}_{2} \mathrm{O} \leftrightarrow \mathrm{HCO}_{3}^{-}+\mathrm{H}^{+}$, and facilitate the transport of $\mathrm{CO}_{2}$ and $\mathrm{H}^{+}$ions for $\mathrm{pH}$ regulation (Swietach et al., 2010). There are $15 \mathrm{CA}$ isoforms, I to $\mathrm{XV}$, in mammalian cells, located in the cytosol, mitochondrion, extracellular plasma membrane, or secreted. In particular, the isoform IX (CAIX) has been extensively studied in cancer biology (Swietach et al., 2010). The expression of CAIX is strongly induced by hypoxia and regulated by HIF-1. 
CAIX has been used as an endogenous marker to delineate hypoxic regions in solid tumors and is a prognostic marker of aggressive cancers. Inhibition of CAIX has been shown to suppress tumor growth in xenograft models (Chiche et al., 2009). CAIX small molecule inhibitors and antibodies have been developed and evaluated as potential anti-cancer therapeutics. A CAIX monoclonal antibody exhibited anti-tumor activities in the mouse xenograft model of colorectal cancer (Zatovicova et al., 2010). Moreover, CAIX inhibitors were shown to increase the therapeutic effects of tumor radiation (Dubois et al., 2011).

Monocarboxylate transporters (MCT) facilitate the efflux of lactate and protons from cells. The up-regulation of MCTs has been observed in a variety of tumors such as breast, colorectal, ovarian, prostate, and central nervous system carcinomas, and associated with cancer progression and poor prognosis in some instances (Fang et al., 2006; Froberg et al., 2001; Pertega-Gomes et al., 2011; Pinheiro et al., 2010; Pinheiro et al., 2008). MCT1 and MCT4 were related to the invasiveness of human lung cancer cells and drug resistance of ovarian cancer cells (Chen et al., 2010; Izumi et al., 2011). Inhibition of MCT1 could retard the growth of cancer cells in culture and animal models (Fang et al., 2006; Sonveaux et al., 2008). MCTs may, therefore, represent potential targets for cancer treatment.

Vacuolar-type $\mathrm{H}^{+}$-ATPases (V-ATPases) are multi-subunit, complex enzymes that transport protons from the cytoplasm to vacuolar lumens or to extracellular space (Izumi et al., 2003). These proton pumps are important for maintaining intracellular and extracellular $\mathrm{pH}$ homeostasis. V-ATPases overexpression has been detected in many types of tumors such as oral squamous cell cancer and melanoma (Nishisho et al., 2011; Perez-Sayans et al., 2010). Studies showed that V-ATPases increased cancer metastasis and drug resistance (Nishisho et al., 2011; You et al., 2009). Inhibition of V-ATPases by small molecule inhibitors or small interfering RNA suppressed tumor growth and metastasis, induced tumor cell apoptosis, and overcame chemoresistance in several cancer models (De Milito et al., 2007; Lu et al., 2005; Nishisho et al., 2011; You et al., 2009).

Sodium/hydrogen exchangers (NHE) regulate the $\mathrm{pH}$ homeostasis of cells by extruding intracellular $\mathrm{H}^{+}$in exchange of extracellular $\mathrm{Na}^{+}$at a 1:1 ratio. Nine NHE isoforms have been identified in mammalian cells (De Vito, 2006). NHEs were found to regulate cytoskeletal structures and tumor cell migration and invasion (Paradiso et al., 2004). Treatment with NHE1 inhibitors sensitized the paclitaxel-induced apoptosis of human breast cancer cells (Reshkin et al., 2003). Moreover, increased activity of NHE was observed in doxorubicinresistant human colon cancer cells and the treatment with the NHE inhibitor 5-(N-ethyl-Nisopropyl)-amiloride (EIPA) sensitized the resistant cells to doxorubicin (Miraglia et al., 2005). Inhibition of NHEs has also been shown to reduce the proliferation and VEGF production of leukemia cells (He et al., 2007; Turturro et al., 2007).

Proton-sensing G protein-coupled receptors (GPCRs), including GPR4, TDAG8 (GPR65), OGR1 (GPR68), and G2A (GPR132), can be activated by acidic extracellular pH to transduce multiple downstream signaling pathways such as the $\mathrm{G}_{\mathrm{s}} / \mathrm{cAMP} \mathrm{G}_{\mathrm{q}} /$ phospholipase $\mathrm{C} / \mathrm{Ca}^{2+}$, and $G_{13}$ / Rho pathways (Ludwig et al., 2003; Murakami et al., 2004; Radu et al., 2005; Tobo et al., 2007; Wang et al., 2004; Yang et al., 2007). Different from the proton transporters, the proton-sensing GPCRs do not directly transport protons but, instead, perceive acidic extracellular $\mathrm{pH}$ to trigger signal transduction. Potential roles of the proton-sensing GPCRs in cancer biology have been emerging, with differential roles for each family member in a cell context-dependent manner. Activation of GPR4 by acidic $\mathrm{pH}$ has been shown to inhibit 
tumor cell migration, invasion and metastasis and suppress microvascular outgrowth (Castellone et al., 2011; Yang et al., 2007). Overexpression of OGR1 also inhibited the migration and metastasis of prostate cancer cells and the effects were attributed to the constitutive activity of the receptor but not $\mathrm{pH}$ sensing function (Singh et al., 2007). Overexpression of TDAG8, however, enhanced the development of lung cancer cells (Ihara et al., 2010). TDAG8, as well as GPR4, exhibited transforming activities when ectopically overexpressed in immortalized cell lines (Sin et al., 2004). Furthermore, the proton-sensing GPCRs have been shown to regulate immune cell function and inflammatory responses (Ichimonji et al., 2010; Mogi et al., 2009; Onozawa et al., 2011). These observations suggest that the proton-sensing GPCRs may represent novel targets for cancer treatment, inflammation inhibition, and chemoprevention.

Taken together, the acid-base transporters and proton-sensing receptors described above are important for cancer cells to sense and adapt to the acidic tumor microenvironment. Further research is warranted to validate these $\mathrm{pH}$ regulators as potential targets for cancer therapy and chemoprevention. Moreover, acidity itself in the tumor microenvironment can also be exploited for cancer detection and treatment. Recent studies showed that a technology using the $\mathrm{pH}$ low insertion peptide (pHLIP), a peptide that forms a-helix at acidic $\mathrm{pH}$ and inserts across cell membrane, could be applied to image prostate cancer xenografts in mice by positron emission tomography (Vavere et al., 2009). Acidity in the tumor microenvironment may also be utilized to design pro-drugs that are activated or become more potent at acidic $\mathrm{pH}$ to differentially kill cancer cells.

\section{Concluding remarks}

Cancer cells do not exist in isolation; instead, they closely interact with blood vessels, inflammatory cells, and fibroblasts in a unique tumor microenvironment characterized by hypoxia and acidosis. The interaction between cancer cells and the tumor microenvironment plays a pivotal role in cancer progression and somatic evolution, which follows very similar principles of Darwinian selection. It is increasingly recognized that in addition to killing cancer cells, targeting the components of the tumor microenvironment can help develop more effective approaches for cancer prevention and therapy. For instance, antiangiogenesis therapy, combined with conventional chemotherapy, has shown significant clinical benefits in multiple cancer types (Ferrara and Kerbel, 2005; Kerbel, 2008). Furthermore, a number of agents targeting inflammation, cancer cell metabolism, and hypoxia and acidosis pathways have been developed and added to the arsenal for cancer treatment, detection, diagnosis, prognosis and chemoprevention.

While significant progress has been made to understand the tumor-microenvironment interaction, considerable knowledge gaps still remain. This aspect is exemplified by the lessons learned from anti-angiogenesis therapy. Whereas angiogenesis inhibitors have offered therapeutic benefits in cancer patients, some unexpected adverse effects deserve a close attention. In certain experimental settings, anti-angiogenesis therapy has been shown to promote tumor invasion and metastasis (De Bock et al., 2011; Ebos and Kerbel, 2011; Ebos et al., 2009). The underlying cause is largely attributed to the anti-angiogenesis therapyinduced hypoxia, which is known to stimulate cancer cell metastasis. These observations illustrate that cancer cells constantly evolve and adapt to the changing tumor microenvironment during therapeutic interventions and/or tumor development. In 
addition to hypoxia, other microenvironmental factors, such as acidosis and low nutrients, are also important selection forces that have a significant impact on cancer cell somatic evolution. The experience of anti-angiogenesis therapy once again underscores the fact that tumors comprise not just cancer cells and these cancer cells are continuously evolving. It is necessary to target multiple cell components and molecular pathways (both cancer cellintrinsic and microenvironment-related) in order to devise more effective strategies for the treatment and prevention of cancer.

\section{Acknowledgment}

We thank Dr. Adam Asch for reading the manuscript. The research in the authors' laboratory has been supported by the American Heart Association, Brody Brothers Endowment Fund, Golfers against Cancer, and North Carolina Biotechnology Center (to L.V.Y). We apologize to these whose work could not be cited due to the space limitation of this manuscript.

\section{References}

Abramsson, A., Berlin, O., Papayan, H., Paulin, D., Shani, M., and Betsholtz, C. (2002). Analysis of mural cell recruitment to tumor vessels. Circulation 105, 112-117.

Abramsson, A., Lindblom, P., and Betsholtz, C. (2003). Endothelial and nonendothelial sources of PDGF-B regulate pericyte recruitment and influence vascular pattern formation in tumors. J Clin Invest 112, 1142-1151.

Adini, A., Kornaga, T., Firoozbakht, F., and Benjamin, L.E. (2002). Placental growth factor is a survival factor for tumor endothelial cells and macrophages. Cancer Res 62, 27492752.

Al-Hajj, M., Wicha, M.S., Benito-Hernandez, A., Morrison, S.J., and Clarke, M.F. (2003). Prospective identification of tumorigenic breast cancer cells. Proc Natl Acad Sci U S A 100, 3983-3988.

Ara, T., and Declerck, Y.A. (2010). Interleukin-6 in bone metastasis and cancer progression. Eur J Cancer 46, 1223-1231.

Augustin, H.G., Koh, G.Y., Thurston, G., and Alitalo, K. (2009). Control of vascular morphogenesis and homeostasis through the angiopoietin-Tie system. Nat Rev Mol Cell Biol 10, 165-177.

Azab, A.K., Runnels, J.M., Pitsillides, C., Moreau, A.S., Azab, F., Leleu, X., Jia, X., Wright, R., Ospina, B., Carlson, A.L., et al. (2009). CXCR4 inhibitor AMD3100 disrupts the interaction of multiple myeloma cells with the bone marrow microenvironment and enhances their sensitivity to therapy. Blood 113, 4341-4351.

Baeriswyl, V., and Christofori, G. (2009). The angiogenic switch in carcinogenesis. Semin Cancer Biol 19, 329-337.

Baluk, P., Hashizume, H., and McDonald, D.M. (2005). Cellular abnormalities of blood vessels as targets in cancer. Curr Opin Genet Dev 15, 102-111.

Baron, J.A., Sandler, R.S., Bresalier, R.S., Lanas, A., Morton, D.G., Riddell, R., Iverson, E.R., and Demets, D.L. (2008). Cardiovascular events associated with rofecoxib: final analysis of the APPROVe trial. Lancet 372, 1756-1764.

Beenken, A., and Mohammadi, M. (2009). The FGF family: biology, pathophysiology and therapy. Nat Rev Drug Discov 8, 235-253. 
Bergers, G., and Benjamin, L.E. (2003). Tumorigenesis and the angiogenic switch. Nat Rev Cancer 3, 401-410.

Bergers, G., and Hanahan, D. (2008). Modes of resistance to anti-angiogenic therapy. Nat Rev Cancer 8, 592-603.

Bergers, G., Song, S., Meyer-Morse, N., Bergsland, E., and Hanahan, D. (2003). Benefits of targeting both pericytes and endothelial cells in the tumor vasculature with kinase inhibitors. J Clin Invest 111, 1287-1295.

Bertout, J.A., Patel, S.A., and Simon, M.C. (2008). The impact of O2 availability on human cancer. Nat Rev Cancer 8, 967-975.

Bhowmick, N.A., Neilson, E.G., and Moses, H.L. (2004). Stromal fibroblasts in cancer initiation and progression. Nature 432, 332-337.

Bo, S., Ciccone, G., Rosato, R., Villois, P., Appendino, G., Ghigo, E., and Grassi, G. (2011). Cancer mortality reduction and metformin. A retrospective cohort study in type 2 diabetic patients. Diabetes Obes Metab.

Boire, A., Covic, L., Agarwal, A., Jacques, S., Sherifi, S., and Kuliopulos, A. (2005). PAR1 is a matrix metalloprotease- 1 receptor that promotes invasion and tumorigenesis of breast cancer cells. Cell 120, 303-313.

Bonnet, D., and Dick, J.E. (1997). Human acute myeloid leukemia is organized as a hierarchy that originates from a primitive hematopoietic cell. Nat Med 3, 730-737.

Botting, R.M. (2010). Vane's discovery of the mechanism of action of aspirin changed our understanding of its clinical pharmacology. Pharmacol Rep 62, 518-525.

Bourguignon, L.Y., Singleton, P.A., Diedrich, F., Stern, R., and Gilad, E. (2004). CD44 interaction with $\mathrm{Na}+-\mathrm{H}+$ exchanger (NHE1) creates acidic microenvironments leading to hyaluronidase-2 and cathepsin B activation and breast tumor cell invasion. J Biol Chem 279, 26991-27007.

Buerkle, A., and Weber, W.A. (2008). Imaging of tumor glucose utilization with positron emission tomography. Cancer Metastasis Rev 27, 545-554.

Cairns, R., Papandreou, I., and Denko, N. (2006). Overcoming physiologic barriers to cancer treatment by molecularly targeting the tumor microenvironment. Mol Cancer Res 4, 61-70.

Cairns, R.A., Harris, I.S., and Mak, T.W. (2011). Regulation of cancer cell metabolism. Nat Rev Cancer 11, 85-95.

Carmeliet, P., and Jain, R.K. (2000). Angiogenesis in cancer and other diseases. Nature 407, 249-257.

Castellone, R.D., Leffler, N.R., Dong, L., and Yang, L.V. (2011). Inhibition of tumor cell migration and metastasis by the proton-sensing GPR4 receptor. Cancer Lett 312, 197-208

Castor, C.W., Wilson, S.M., Heiss, P.R., and Seidman, J.C. (1979). Activation of lung connective tissue cells in vitro. Am Rev Respir Dis 120, 101-106.

Chan, D.A., Sutphin, P.D., Nguyen, P., Turcotte, S., Lai, E.W., Banh, A., Reynolds, G.E., Chi, J.T., Wu, J., Solow-Cordero, D.E., et al. (2011). Targeting GLUT1 and the Warburg Effect in Renal Cell Carcinoma by Chemical Synthetic Lethality. Sci Transl Med 3, 94ra70.

Chang, H.Y., Chi, J.T., Dudoit, S., Bondre, C., van de Rijn, M., Botstein, D., and Brown, P.O. (2002). Diversity, topographic differentiation, and positional memory in human fibroblasts. Proc Natl Acad Sci U S A 99, 12877-12882. 
Chang, Q., Jurisica, I., Do, T., and Hedley, D.W. (2011). Hypoxia predicts aggressive growth and spontaneous metastasis formation from orthotopically grown primary xenografts of human pancreatic cancer. Cancer Res 71, 3110-3120.

Chen, H., Wang, L., Beretov, J., Hao, J., Xiao, W., and Li, Y. (2010). Co-expression of CD147/EMMPRIN with monocarboxylate transporters and multiple drug resistance proteins is associated with epithelial ovarian cancer progression. Clin Exp Metastasis 27, 557-569.

Chen, Y., Wiesmann, C., Fuh, G., Li, B., Christinger, H.W., McKay, P., de Vos, A.M., and Lowman, H.B. (1999). Selection and analysis of an optimized anti-VEGF antibody: crystal structure of an affinity-matured Fab in complex with antigen. J Mol Biol 293, 865-881.

Chiche, J., Ilc, K., Laferriere, J., Trottier, E., Dayan, F., Mazure, N.M., Brahimi-Horn, M.C., and Pouyssegur, J. (2009). Hypoxia-inducible carbonic anhydrase IX and XII promote tumor cell growth by counteracting acidosis through the regulation of the intracellular pH. Cancer Res 69, 358-368.

Chiu, P.P., Jiang, H., and Dick, J.E. (2010). Leukemia-initiating cells in human Tlymphoblastic leukemia exhibit glucocorticoid resistance. Blood 116, 5268-5279.

Cho, R.W., and Clarke, M.F. (2008). Recent advances in cancer stem cells. Curr Opin Genet Dev 18, 48-53.

Chouaib, S., Kieda, C., Benlalam, H., Noman, M.Z., Mami-Chouaib, F., and Ruegg, C. (2010). Endothelial cells as key determinants of the tumor microenvironment: interaction with tumor cells, extracellular matrix and immune killer cells. Crit Rev Immunol 30, 529-545.

Clarke, M.F., Dick, J.E., Dirks, P.B., Eaves, C.J., Jamieson, C.H., Jones, D.L., Visvader, J., Weissman, I.L., and Wahl, G.M. (2006). Cancer stem cells--perspectives on current status and future directions: AACR Workshop on cancer stem cells. Cancer Res 66, 9339-9344.

Clevers, H. (2011). The cancer stem cell: premises, promises and challenges. Nat Med 17, 313-319.

Cohen, M.H., Shen, Y.L., Keegan, P., and Pazdur, R. (2009). FDA drug approval summary: bevacizumab (Avastin) as treatment of recurrent glioblastoma multiforme. Oncologist 14, 1131-1138.

Cook, N.R., Lee, I.M., Gaziano, J.M., Gordon, D., Ridker, P.M., Manson, J.E., Hennekens, C.H., and Buring, J.E. (2005). Low-dose aspirin in the primary prevention of cancer: the Women's Health Study: a randomized controlled trial. JAMA 294, 47-55.

Cozzio, A., Passegue, E., Ayton, P.M., Karsunky, H., Cleary, M.L., and Weissman, I.L. (2003). Similar MLL-associated leukemias arising from self-renewing stem cells and shortlived myeloid progenitors. Genes Dev 17, 3029-3035.

Currie, G.P., Kennedy, A.M., Paterson, E., and Watt, S.J. (2007). A chronic pneumothorax and fitness to fly. Thorax 62, 187-189.

Dalerba, P., Dylla, S.J., Park, I.K., Liu, R., Wang, X., Cho, R.W., Hoey, T., Gurney, A., Huang, E.H., Simeone, D.M., et al. (2007). Phenotypic characterization of human colorectal cancer stem cells. Proc Natl Acad Sci U S A 104, 10158-10163.

Dang, C.V., Le, A., and Gao, P. (2009). MYC-induced cancer cell energy metabolism and therapeutic opportunities. Clin Cancer Res 15, 6479-6483. 
De Bock, K., Mazzone, M., and Carmeliet, P. (2011). Antiangiogenic therapy, hypoxia, and metastasis: risky liaisons, or not? Nat Rev Clin Oncol 8, 393-404.

De Milito, A., Iessi, E., Logozzi, M., Lozupone, F., Spada, M., Marino, M.L., Federici, C., Perdicchio, M., Matarrese, P., Lugini, L., et al. (2007). Proton pump inhibitors induce apoptosis of human B-cell tumors through a caspase-independent mechanism involving reactive oxygen species. Cancer Res 67, 5408-5417.

de Visser, K.E. (2008). Spontaneous immune responses to sporadic tumors: tumorpromoting, tumor-protective or both? Cancer Immunol Immunother 57, 1531-1539.

de Visser, K.E., Eichten, A., and Coussens, L.M. (2006). Paradoxical roles of the immune system during cancer development. Nat Rev Cancer 6, 24-37.

De Vito, P. (2006). The sodium/hydrogen exchanger: a possible mediator of immunity. Cell Immunol 240, 69-85.

Diehn, M., Cho, R.W., Lobo, N.A., Kalisky, T., Dorie, M.J., Kulp, A.N., Qian, D., Lam, J.S., Ailles, L.E., Wong, M., et al. (2009). Association of reactive oxygen species levels and radioresistance in cancer stem cells. Nature 458, 780-783.

DiPersio, J.F., Micallef, I.N., Stiff, P.J., Bolwell, B.J., Maziarz, R.T., Jacobsen, E., Nademanee, A., McCarty, J., Bridger, G., and Calandra, G. (2009a). Phase III prospective randomized double-blind placebo-controlled trial of plerixafor plus granulocyte colony-stimulating factor compared with placebo plus granulocyte colonystimulating factor for autologous stem-cell mobilization and transplantation for patients with non-Hodgkin's lymphoma. J Clin Oncol 27, 4767-4773.

DiPersio, J.F., Stadtmauer, E.A., Nademanee, A., Micallef, I.N., Stiff, P.J., Kaufman, J.L., Maziarz, R.T., Hosing, C., Fruehauf, S., Horwitz, M., et al. (2009b). Plerixafor and GCSF versus placebo and G-CSF to mobilize hematopoietic stem cells for autologous stem cell transplantation in patients with multiple myeloma. Blood 113, 5720-5726.

Dubois, L., Peeters, S., Lieuwes, N.G., Geusens, N., Thiry, A., Wigfield, S., Carta, F., McIntyre, A., Scozzafava, A., Dogne, J.M., et al. (2011). Specific inhibition of carbonic anhydrase IX activity enhances the in vivo therapeutic effect of tumor irradiation. Radiother Oncol 99, 424-431.

Dudley, M.E., Wunderlich, J.R., Robbins, P.F., Yang, J.C., Hwu, P., Schwartzentruber, D.J., Topalian, S.L., Sherry, R., Restifo, N.P., Hubicki, A.M., et al. (2002). Cancer regression and autoimmunity in patients after clonal repopulation with antitumor lymphocytes. Science $298,850-854$.

Dvorak, H.F. (1986). Tumors: wounds that do not heal. Similarities between tumor stroma generation and wound healing. N Engl J Med 315, 1650-1659.

Dvorak, H.F. (2002). Vascular permeability factor/vascular endothelial growth factor: a critical cytokine in tumor angiogenesis and a potential target for diagnosis and therapy. J Clin Oncol 20, 4368-4380.

Ebos, J.M., and Kerbel, R.S. (2011). Antiangiogenic therapy: impact on invasion, disease progression, and metastasis. Nat Rev Clin Oncol 8, 210-221.

Ebos, J.M., Lee, C.R., Cruz-Munoz, W., Bjarnason, G.A., Christensen, J.G., and Kerbel, R.S. (2009). Accelerated metastasis after short-term treatment with a potent inhibitor of tumor angiogenesis. Cancer Cell 15, 232-239.

Eckerich, C., Zapf, S., Fillbrandt, R., Loges, S., Westphal, M., and Lamszus, K. (2007). Hypoxia can induce c-Met expression in glioma cells and enhance SF/HGFinduced cell migration. Int J Cancer 121, 276-283. 
Escudier, B., Eisen, T., Stadler, W.M., Szczylik, C., Oudard, S., Siebels, M., Negrier, S., Chevreau, C., Solska, E., Desai, A.A., et al. (2007). Sorafenib in advanced clear-cell renal-cell carcinoma. N Engl J Med 356, 125-134.

Eskens, F.A., and Verweij, J. (2006). The clinical toxicity profile of vascular endothelial growth factor (VEGF) and vascular endothelial growth factor receptor (VEGFR) targeting angiogenesis inhibitors; a review. Eur J Cancer 42, 3127-3139.

Fabian, M.A., Biggs, W.H., 3rd, Treiber, D.K., Atteridge, C.E., Azimioara, M.D., Benedetti, M.G., Carter, T.A., Ciceri, P., Edeen, P.T., Floyd, M., et al. (2005). A small moleculekinase interaction map for clinical kinase inhibitors. Nat Biotechnol 23, 329-336.

Faivre, S., Demetri, G., Sargent, W., and Raymond, E. (2007). Molecular basis for sunitinib efficacy and future clinical development. Nat Rev Drug Discov 6, 734-745.

Fang, J., Quinones, Q.J., Holman, T.L., Morowitz, M.J., Wang, Q., Zhao, H., Sivo, F., Maris, J.M., and Wahl, M.L. (2006). The H+-linked monocarboxylate transporter (MCT1/SLC16A1): a potential therapeutic target for high-risk neuroblastoma. Mol Pharmacol 70, 2108-2115.

Fernando, N.T., Koch, M., Rothrock, C., Gollogly, L.K., D'Amore, P.A., Ryeom, S., and Yoon, S.S. (2008). Tumor escape from endogenous, extracellular matrix-associated angiogenesis inhibitors by up-regulation of multiple proangiogenic factors. Clin Cancer Res 14, 1529-1539.

Ferrara, N. (2002). VEGF and the quest for tumour angiogenesis factors. Nat Rev Cancer 2, 795-803.

Ferrara, N., Damico, L., Shams, N., Lowman, H., and Kim, R. (2006). Development of ranibizumab, an anti-vascular endothelial growth factor antigen binding fragment, as therapy for neovascular age-related macular degeneration. Retina 26, 859-870.

Ferrara, N., Gerber, H.P., and LeCouter, J. (2003). The biology of VEGF and its receptors. Nat Med 9, 669-676.

Ferrara, N., Hillan, K.J., Gerber, H.P., and Novotny, W. (2004). Discovery and development of bevacizumab, an anti-VEGF antibody for treating cancer. Nat Rev Drug Discov 3, 391-400.

Ferrara, N., and Kerbel, R.S. (2005). Angiogenesis as a therapeutic target. Nature 438, 967974.

Fialkow, P.J. (1990). Stem cell origin of human myeloid blood cell neoplasms. Verh Dtsch Ges Pathol 74, 43-47.

Fidler, I.J. (2002). Critical determinants of metastasis. Semin Cancer Biol 12, 89-96.

Fischer, C., Jonckx, B., Mazzone, M., Zacchigna, S., Loges, S., Pattarini, L., Chorianopoulos, E., Liesenborghs, L., Koch, M., De Mol, M., et al. (2007). Anti-PlGF inhibits growth of $\operatorname{VEGF(R)-inhibitor-resistant~tumors~without~affecting~healthy~vessels.~Cell~131,~}$ 463-475.

Folkman, J. (1971). Tumor angiogenesis: therapeutic implications. N Engl J Med 285, 11821186.

Folkman, J. (2006). Angiogenesis. Annu Rev Med 57, 1-18.

Fridman, W.H., Galon, J., Pages, F., Tartour, E., Sautes-Fridman, C., and Kroemer, G. (2011). Prognostic and predictive impact of intra- and peritumoral immune infiltrates. Cancer Res 71, 5601-5605. 
Froberg, M.K., Gerhart, D.Z., Enerson, B.E., Manivel, C., Guzman-Paz, M., Seacotte, N., and Drewes, L.R. (2001). Expression of monocarboxylate transporter MCT1 in normal and neoplastic human CNS tissues. Neuroreport 12, 761-765.

Fukumura, D., and Jain, R.K. (2007). Tumor microenvironment abnormalities: causes, consequences, and strategies to normalize. J Cell Biochem 101, 937-949.

Gabbiani, G. (2003). The myofibroblast in wound healing and fibrocontractive diseases. J Pathol 200, 500-503.

Gao, F., Liao, C., Liu, L., Tan, A., Cao, Y., and Mo, Z. (2009). The effect of aspirin in the recurrence of colorectal adenomas: a meta-analysis of randomized controlled trials. Colorectal Dis 11, 893-901.

Gatenby, R.A., Gawlinski, E.T., Gmitro, A.F., Kaylor, B., and Gillies, R.J. (2006). Acidmediated tumor invasion: a multidisciplinary study. Cancer Res 66, 5216-5223.

Gatenby, R.A., and Gillies, R.J. (2004). Why do cancers have high aerobic glycolysis? Nat Rev Cancer 4, 891-899.

Gatenby, R.A., and Gillies, R.J. (2007). Glycolysis in cancer: a potential target for therapy. Int J Biochem Cell Biol 39, 1358-1366.

Gatenby, R.A., and Gillies, R.J. (2008). A microenvironmental model of carcinogenesis. Nat Rev Cancer 8, 56-61.

Gerhardt, H., and Betsholtz, C. (2003). Endothelial-pericyte interactions in angiogenesis. Cell Tissue Res 314, 15-23.

Gerweck, L.E., Vijayappa, S., and Kozin, S. (2006). Tumor pH controls the in vivo efficacy of weak acid and base chemotherapeutics. Mol Cancer Ther 5, 1275-1279.

Giantonio, B.J., Catalano, P.J., Meropol, N.J., O'Dwyer, P.J., Mitchell, E.P., Alberts, S.R., Schwartz, M.A., and Benson, A.B., 3rd (2007). Bevacizumab in combination with oxaliplatin, fluorouracil, and leucovorin (FOLFOX4) for previously treated metastatic colorectal cancer: results from the Eastern Cooperative Oncology Group Study E3200. J Clin Oncol 25, 1539-1544.

Gonzalez-Angulo, A.M., and Meric-Bernstam, F. (2010). Metformin: a therapeutic opportunity in breast cancer. Clin Cancer Res 16, 1695-1700.

Goodman, V.L., Rock, E.P., Dagher, R., Ramchandani, R.P., Abraham, S., Gobburu, J.V., Booth, B.P., Verbois, S.L., Morse, D.E., Liang, C.Y., et al. (2007). Approval summary: sunitinib for the treatment of imatinib refractory or intolerant gastrointestinal stromal tumors and advanced renal cell carcinoma. Clin Cancer Res 13, 1367-1373.

Gragoudas, E.S., Adamis, A.P., Cunningham, E.T., Jr., Feinsod, M., and Guyer, D.R. (2004). Pegaptanib for neovascular age-related macular degeneration. N Engl J Med 351, 2805-2816.

Griffiths, J.R., McIntyre, D.J., Howe, F.A., and Stubbs, M. (2001). Why are cancers acidic? A carrier-mediated diffusion model for $\mathrm{H}+$ transport in the interstitial fluid. Novartis Found Symp 240, 46-62; discussion 62-47, 152-153.

Grivennikov, S.I., Greten, F.R., and Karin, M. (2010). Immunity, inflammation, and cancer. Cell 140, 883-899.

Gupta, P.B., Chaffer, C.L., and Weinberg, R.A. (2009). Cancer stem cells: mirage or reality? Nat Med 15, 1010-1012.

Hanahan, D., and Folkman, J. (1996). Patterns and emerging mechanisms of the angiogenic switch during tumorigenesis. Cell 86, 353-364.

Hanahan, D., and Weinberg, R.A. (2000). The hallmarks of cancer. Cell 100, 57-70. 
Hanahan, D., and Weinberg, R.A. (2011). Hallmarks of cancer: the next generation. Cell 144, 646-674.

Hashizume, H., Baluk, P., Morikawa, S., McLean, J.W., Thurston, G., Roberge, S., Jain, R.K., and McDonald, D.M. (2000). Openings between defective endothelial cells explain tumor vessel leakiness. Am J Pathol 156, 1363-1380.

He, B., Deng, C., Zhang, M., Zou, D., and Xu, M. (2007). Reduction of intracellular pH inhibits the expression of VEGF in K562 cells after targeted inhibition of the $\mathrm{Na}+/ \mathrm{H}+$ exchanger. Leuk Res 31, 507-514.

Heddleston, J.M., Li, Z., Lathia, J.D., Bao, S., Hjelmeland, A.B., and Rich, J.N. (2010). Hypoxia inducible factors in cancer stem cells. Br J Cancer 102, 789-795.

Helmlinger, G., Sckell, A., Dellian, M., Forbes, N.S., and Jain, R.K. (2002). Acid production in glycolysis-impaired tumors provides new insights into tumor metabolism. Clin Cancer Res 8, 1284-1291.

Hendricksen, K., van der Heijden, A.G., Cornel, E.B., Vergunst, H., de Reijke, T.M., van Boven, E., Smits, G.A., Puri, R., Gruijs, S., and Witjes, J.A. (2009). Two-year followup of the phase II marker lesion study of intravesical apaziquone for patients with non-muscle invasive bladder cancer. World J Urol 27, 337-342.

Hermann, P.C., Huber, S.L., Herrler, T., Aicher, A., Ellwart, J.W., Guba, M., Bruns, C.J., and Heeschen, C. (2007). Distinct populations of cancer stem cells determine tumor growth and metastatic activity in human pancreatic cancer. Cell Stem Cell 1, 313323.

Hicklin, D.J., and Ellis, L.M. (2005). Role of the vascular endothelial growth factor pathway in tumor growth and angiogenesis. J Clin Oncol 23, 1011-1027.

Higgins, D.F., Kimura, K., Bernhardt, W.M., Shrimanker, N., Akai, Y., Hohenstein, B., Saito, Y., Johnson, R.S., Kretzler, M., Cohen, C.D., et al. (2007). Hypoxia promotes fibrogenesis in vivo via HIF-1 stimulation of epithelial-to-mesenchymal transition. J Clin Invest 117, 3810-3820.

Hill, R., Song, Y., Cardiff, R.D., and Van Dyke, T. (2005). Selective evolution of stromal mesenchyme with p53 loss in response to epithelial tumorigenesis. Cell 123, 10011011.

Hosono, K., Endo, H., Takahashi, H., Sugiyama, M., Sakai, E., Uchiyama, T., Suzuki, K., Iida, H., Sakamoto, Y., Yoneda, K., et al. (2010). Metformin suppresses colorectal aberrant crypt foci in a short-term clinical trial. Cancer Prev Res (Phila) 3, 1077-1083.

Houck, K.A., Ferrara, N., Winer, J., Cachianes, G., Li, B., and Leung, D.W. (1991). The vascular endothelial growth factor family: identification of a fourth molecular species and characterization of alternative splicing of RNA. Mol Endocrinol 5, 18061814.

Hu, M., Yao, J., Cai, L., Bachman, K.E., van den Brule, F., Velculescu, V., and Polyak, K. (2005). Distinct epigenetic changes in the stromal cells of breast cancers. Nat Genet 37, 899-905.

Hugo, H., Ackland, M.L., Blick, T., Lawrence, M.G., Clements, J.A., Williams, E.D., and Thompson, E.W. (2007). Epithelial--mesenchymal and mesenchymal--epithelial transitions in carcinoma progression. J Cell Physiol 213, 374-383.

Hunter, A., Hendrikse, A., Renan, M., and Abratt, R. (2006). Does the tumor microenvironment influence radiation-induced apoptosis? Apoptosis 11, 1727-1735. 
Hurwitz, H., Fehrenbacher, L., Novotny, W., Cartwright, T., Hainsworth, J., Heim, W., Berlin, J., Baron, A., Griffing, S., Holmgren, E., et al. (2004). Bevacizumab plus irinotecan, fluorouracil, and leucovorin for metastatic colorectal cancer. N Engl J Med 350, 2335-2342.

Ichimonji, I., Tomura, H., Mogi, C., Sato, K., Aoki, H., Hisada, T., Dobashi, K., Ishizuka, T., Mori, M., and Okajima, F. (2010). Extracellular acidification stimulates IL-6 production and $\mathrm{Ca}(2+)$ mobilization through proton-sensing OGR1 receptors in human airway smooth muscle cells. Am J Physiol Lung Cell Mol Physiol 299, L567577.

Ihara, Y., Kihara, Y., Hamano, F., Yanagida, K., Morishita, Y., Kunita, A., Yamori, T., Fukayama, M., Aburatani, H., Shimizu, T., et al. (2010). The G protein-coupled receptor T-cell death-associated gene 8 (TDAG8) facilitates tumor development by serving as an extracellular pH sensor. Proc Natl Acad Sci U S A 107, 17309-17314.

Isaacs, J.S., Jung, Y.J., Mimnaugh, E.G., Martinez, A., Cuttitta, F., and Neckers, L.M. (2002). Hsp90 regulates a von Hippel Lindau-independent hypoxia-inducible factor-1 alpha-degradative pathway. J Biol Chem 277, 29936-29944.

Izumi, H., Takahashi, M., Uramoto, H., Nakayama, Y., Oyama, T., Wang, K.Y., Sasaguri, Y., Nishizawa, S., and Kohno, K. (2011). Monocarboxylate transporters 1 and 4 are involved in the invasion activity of human lung cancer cells. Cancer Sci 102, 10071013.

Izumi, H., Torigoe, T., Ishiguchi, H., Uramoto, H., Yoshida, Y., Tanabe, M., Ise, T., Murakami, T., Yoshida, T., Nomoto, M., et al. (2003). Cellular pH regulators: potentially promising molecular targets for cancer chemotherapy. Cancer Treat Rev 29, 541-549.

Jain, A., Phillips, R.M., Scally, A.J., Lenaz, G., Beer, M., and Puri, R. (2009). Response of multiple recurrent TaT1 bladder cancer to intravesical apaziquone (EO9): comparative analysis of tumor recurrence rates. Urology 73, 1083-1086.

Jain, R.K. (2005). Normalization of tumor vasculature: an emerging concept in antiangiogenic therapy. Science 307, 58-62.

Jiang, L., Gonda, T.A., Gamble, M.V., Salas, M., Seshan, V., Tu, S., Twaddell, W.S., Hegyi, P., Lazar, G., Steele, I., et al. (2008). Global hypomethylation of genomic DNA in cancer-associated myofibroblasts. Cancer Res 68, 9900-9908.

Johnson, L.L., Pavlovsky, A.G., Johnson, A.R., Janowicz, J.A., Man, C.F., Ortwine, D.F., Purchase, C.F., 2nd, White, A.D., and Hupe, D.J. (2000). A rationalization of the acidic $\mathrm{pH}$ dependence for stromelysin-1 (Matrix metalloproteinase-3) catalysis and inhibition. J Biol Chem 275, 11026-11033.

Joyce, J.A., and Pollard, J.W. (2009). Microenvironmental regulation of metastasis. Nat Rev Cancer 9, 239-252.

Karnoub, A.E., and Weinberg, R.A. (2006). Chemokine networks and breast cancer metastasis. Breast Dis 26, 75-85.

Kashfi, K. (2009). Anti-inflammatory agents as cancer therapeutics. Adv Pharmacol 57, 3189.

Kazerounian, S., Yee, K.O., and Lawler, J. (2008). Thrombospondins in cancer. Cell Mol Life Sci $65,700-712$.

Kelly, P.N., Dakic, A., Adams, J.M., Nutt, S.L., and Strasser, A. (2007). Tumor growth need not be driven by rare cancer stem cells. Science $317,337$. 
Kerbel, R., and Folkman, J. (2002). Clinical translation of angiogenesis inhibitors. Nat Rev Cancer 2, 727-739.

Kerbel, R.S. (2008). Tumor angiogenesis. N Engl J Med 358, 2039-2049.

Kiaris, H., Chatzistamou, I., Trimis, G., Frangou-Plemmenou, M., Pafiti-Kondi, A., and Kalofoutis, A. (2005). Evidence for nonautonomous effect of p53 tumor suppressor in carcinogenesis. Cancer Res 65, 1627-1630.

Kienast, Y., von Baumgarten, L., Fuhrmann, M., Klinkert, W.E., Goldbrunner, R., Herms, J., and Winkler, F. (2010). Real-time imaging reveals the single steps of brain metastasis formation. Nat Med 16, 116-122.

Kim, M., Koh, Y.J., Kim, K.E., Koh, B.I., Nam, D.H., Alitalo, K., Kim, I., and Koh, G.Y. (2010). CXCR4 signaling regulates metastasis of chemoresistant melanoma cells by a lymphatic metastatic niche. Cancer Res 70, 10411-10421.

Kim, R., Emi, M., and Tanabe, K. (2007). Cancer immunoediting from immune surveillance to immune escape. Immunology 121, 1-14.

Kindler, H.L., Niedzwiecki, D., Hollis, D., Sutherland, S., Schrag, D., Hurwitz, H., Innocenti, F., Mulcahy, M.F., O'Reilly, E., Wozniak, T.F., et al. (2010). Gemcitabine plus bevacizumab compared with gemcitabine plus placebo in patients with advanced pancreatic cancer: phase III trial of the Cancer and Leukemia Group B (CALGB 80303). J Clin Oncol 28, 3617-3622.

Krivtsov, A.V., Twomey, D., Feng, Z., Stubbs, M.C., Wang, Y., Faber, J., Levine, J.E., Wang, J., Hahn, W.C., Gilliland, D.G., et al. (2006). Transformation from committed progenitor to leukaemia stem cell initiated by MLL-AF9. Nature 442, 818-822.

Kupsch, P., Henning, B.F., Passarge, K., Richly, H., Wiesemann, K., Hilger, R.A., Scheulen, M.E., Christensen, O., Brendel, E., Schwartz, B., et al. (2005). Results of a phase I trial of sorafenib (BAY 43-9006) in combination with oxaliplatin in patients with refractory solid tumors, including colorectal cancer. Clin Colorectal Cancer 5, 188196.

Kurose, K., Gilley, K., Matsumoto, S., Watson, P.H., Zhou, X.P., and Eng, C. (2002). Frequent somatic mutations in PTEN and TP53 are mutually exclusive in the stroma of breast carcinomas. Nat Genet 32, 355-357.

Kwitkowski, V.E., Prowell, T.M., Ibrahim, A., Farrell, A.T., Justice, R., Mitchell, S.S., Sridhara, R., and Pazdur, R. (2010). FDA approval summary: temsirolimus as treatment for advanced renal cell carcinoma. Oncologist 15, 428-435.

Lang, L. (2008). FDA approves sorafenib for patients with inoperable liver cancer. Gastroenterology 134, 379.

Lapidot, T., Sirard, C., Vormoor, J., Murdoch, B., Hoang, T., Caceres-Cortes, J., Minden, M., Paterson, B., Caligiuri, M.A., and Dick, J.E. (1994). A cell initiating human acute myeloid leukaemia after transplantation into SCID mice. Nature 367, 645-648.

Lazennec, G., and Richmond, A. (2010). Chemokines and chemokine receptors: new insights into cancer-related inflammation. Trends Mol Med 16, 133-144.

Lenzer, J. (2011). FDA committee votes to withdraw bevacizumab for breast cancer. BMJ $343, \mathrm{~d} 4244$.

Li, C., Heidt, D.G., Dalerba, P., Burant, C.F., Zhang, L., Adsay, V., Wicha, M., Clarke, M.F., and Simeone, D.M. (2007). Identification of pancreatic cancer stem cells. Cancer Res $67,1030-1037$. 
Li, D. (2011). Metformin as an Antitumor Agent in Cancer Prevention and Treatment. J Diabetes.

Li, X., Lewis, M.T., Huang, J., Gutierrez, C., Osborne, C.K., Wu, M.F., Hilsenbeck, S.G., Pavlick, A., Zhang, X., Chamness, G.C., et al. (2008). Intrinsic resistance of tumorigenic breast cancer cells to chemotherapy. J Natl Cancer Inst 100, 672-679.

Lindahl, P., Johansson, B.R., Leveen, P., and Betsholtz, C. (1997). Pericyte loss and microaneurysm formation in PDGF-B-deficient mice. Science 277, 242-245.

Llovet, J.M., Ricci, S., Mazzaferro, V., Hilgard, P., Gane, E., Blanc, J.F., de Oliveira, A.C., Santoro, A., Raoul, J.L., Forner, A., et al. (2008). Sorafenib in advanced hepatocellular carcinoma. N Engl J Med 359, 378-390.

Loar, P., Wahl, H., Kshirsagar, M., Gossner, G., Griffith, K., and Liu, J.R. (2010). Inhibition of glycolysis enhances cisplatin-induced apoptosis in ovarian cancer cells. Am J Obstet Gynecol 202, 371 e371-378.

Lobo, N.A., Shimono, Y., Qian, D., and Clarke, M.F. (2007). The biology of cancer stem cells. Annu Rev Cell Dev Biol 23, 675-699.

Lobov, I.B., Renard, R.A., Papadopoulos, N., Gale, N.W., Thurston, G., Yancopoulos, G.D., and Wiegand, S.J. (2007). Delta-like ligand 4 (Dll4) is induced by VEGF as a negative regulator of angiogenic sprouting. Proc Natl Acad Sci U S A 104, 32193224.

Lorusso, G., and Ruegg, C. (2008). The tumor microenvironment and its contribution to tumor evolution toward metastasis. Histochem Cell Biol 130, 1091-1103.

Lu, X., Qin, W., Li, J., Tan, N., Pan, D., Zhang, H., Xie, L., Yao, G., Shu, H., Yao, M., et al. (2005). The growth and metastasis of human hepatocellular carcinoma xenografts are inhibited by small interfering RNA targeting to the subunit ATP6L of proton pump. Cancer Res 65, 6843-6849.

Ludwig, M.G., Vanek, M., Guerini, D., Gasser, J.A., Jones, C.E., Junker, U., Hofstetter, H., Wolf, R.M., and Seuwen, K. (2003). Proton-sensing G-protein-coupled receptors. Nature 425, 93-98.

Luo, J., Solimini, N.L., and Elledge, S.J. (2009). Principles of cancer therapy: oncogene and non-oncogene addiction. Cell 136, 823-837.

Lyden, D., Hattori, K., Dias, S., Costa, C., Blaikie, P., Butros, L., Chadburn, A., Heissig, B., Marks, W., Witte, L., et al. (2001). Impaired recruitment of bone-marrow-derived endothelial and hematopoietic precursor cells blocks tumor angiogenesis and growth. Nat Med 7, 1194-1201.

Maeshima, A.M., Niki, T., Maeshima, A., Yamada, T., Kondo, H., and Matsuno, Y. (2002). Modified scar grade: a prognostic indicator in small peripheral lung adenocarcinoma. Cancer 95, 2546-2554.

Mani, S.A., Guo, W., Liao, M.J., Eaton, E.N., Ayyanan, A., Zhou, A.Y., Brooks, M., Reinhard, F., Zhang, C.C., Shipitsin, M., et al. (2008). The epithelial-mesenchymal transition generates cells with properties of stem cells. Cell 133, 704-715.

McDonald, D.M., and Choyke, P.L. (2003). Imaging of angiogenesis: from microscope to clinic. Nat Med 9, 713-725.

Michelakis, E.D., Sutendra, G., Dromparis, P., Webster, L., Haromy, A., Niven, E., Maguire, C., Gammer, T.L., Mackey, J.R., Fulton, D., et al. (2010). Metabolic modulation of glioblastoma with dichloroacetate. Sci Transl Med 2, 31ra34. 
Miles, D.W., Chan, A., Dirix, L.Y., Cortes, J., Pivot, X., Tomczak, P., Delozier, T., Sohn, J.H., Provencher, L., Puglisi, F., et al. (2010). Phase III study of bevacizumab plus docetaxel compared with placebo plus docetaxel for the first-line treatment of human epidermal growth factor receptor 2-negative metastatic breast cancer. J Clin Oncol 28, 3239-3247.

Miller, K., Wang, M., Gralow, J., Dickler, M., Cobleigh, M., Perez, E.A., Shenkier, T., Cella, D., and Davidson, N.E. (2007). Paclitaxel plus bevacizumab versus paclitaxel alone for metastatic breast cancer. N Engl J Med 357, 2666-2676.

Miraglia, E., Viarisio, D., Riganti, C., Costamagna, C., Ghigo, D., and Bosia, A. (2005). $\mathrm{Na}+/ \mathrm{H}+$ exchanger activity is increased in doxorubicin-resistant human colon cancer cells and its modulation modifies the sensitivity of the cells to doxorubicin. Int J Cancer 115, 924-929.

Modi, S., Stopeck, A., Linden, H., Solit, D., Chandarlapaty, S., Rosen, N., D'Andrea, G., Dickler, M., Moynahan, M.E., Sugarman, S., et al. (2011). HSP90 Inhibition Is Effective in Breast Cancer: A Phase II Trial of Tanespimycin (17-AAG) Plus Trastuzumab in Patients with HER2-Positive Metastatic Breast Cancer Progressing on Trastuzumab. Clin Cancer Res 17, 5132-5139.

Mogi, C., Tobo, M., Tomura, H., Murata, N., He, X.D., Sato, K., Kimura, T., Ishizuka, T., Sasaki, T., Sato, T., et al. (2009). Involvement of proton-sensing TDAG8 in extracellular acidification-induced inhibition of proinflammatory cytokine production in peritoneal macrophages. J Immunol 182, 3243-3251.

Moinfar, F., Man, Y.G., Arnould, L., Bratthauer, G.L., Ratschek, M., and Tavassoli, F.A. (2000). Concurrent and independent genetic alterations in the stromal and epithelial cells of mammary carcinoma: implications for tumorigenesis. Cancer Res 60, 2562-2566.

Morel, A.P., Lievre, M., Thomas, C., Hinkal, G., Ansieau, S., and Puisieux, A. (2008). Generation of breast cancer stem cells through epithelial-mesenchymal transition. PLoS One 3, e2888.

Morikawa, S., Baluk, P., Kaidoh, T., Haskell, A., Jain, R.K., and McDonald, D.M. (2002). Abnormalities in pericytes on blood vessels and endothelial sprouts in tumors. Am J Pathol 160, 985-1000.

Motzer, R.J., Escudier, B., Oudard, S., Hutson, T.E., Porta, C., Bracarda, S., Grunwald, V., Thompson, J.A., Figlin, R.A., Hollaender, N., et al. (2008). Efficacy of everolimus in advanced renal cell carcinoma: a double-blind, randomised, placebo-controlled phase III trial. Lancet 372, 449-456.

Motzer, R.J., Hutson, T.E., Tomczak, P., Michaelson, M.D., Bukowski, R.M., Oudard, S., Negrier, S., Szczylik, C., Pili, R., Bjarnason, G.A., et al. (2009). Overall survival and updated results for sunitinib compared with interferon alfa in patients with metastatic renal cell carcinoma. J Clin Oncol 27, 3584-3590.

Motzer, R.J., Michaelson, M.D., Redman, B.G., Hudes, G.R., Wilding, G., Figlin, R.A., Ginsberg, M.S., Kim, S.T., Baum, C.M., DePrimo, S.E., et al. (2006). Activity of SU11248, a multitargeted inhibitor of vascular endothelial growth factor receptor and platelet-derived growth factor receptor, in patients with metastatic renal cell carcinoma. J Clin Oncol 24, 16-24.

Muller, G.A., and Rodemann, H.P. (1991). Characterization of human renal fibroblasts in health and disease: I. Immunophenotyping of cultured tubular epithelial cells and 
fibroblasts derived from kidneys with histologically proven interstitial fibrosis. Am J Kidney Dis 17, 680-683.

Murakami, N., Yokomizo, T., Okuno, T., and Shimizu, T. (2004). G2A is a proton-sensing Gprotein-coupled receptor antagonized by lysophosphatidylcholine. J Biol Chem $279,42484-42491$.

Murdoch, C., Muthana, M., Coffelt, S.B., and Lewis, C.E. (2008). The role of myeloid cells in the promotion of tumour angiogenesis. Nat Rev Cancer 8, 618-631.

Nervi, B., Ramirez, P., Rettig, M.P., Uy, G.L., Holt, M.S., Ritchey, J.K., Prior, J.L., PiwnicaWorms, D., Bridger, G., Ley, T.J., et al. (2009). Chemosensitization of acute myeloid leukemia (AML) following mobilization by the CXCR4 antagonist AMD3100. Blood 113, 6206-6214.

Ng, E.W., Shima, D.T., Calias, P., Cunningham, E.T., Jr., Guyer, D.R., and Adamis, A.P. (2006). Pegaptanib, a targeted anti-VEGF aptamer for ocular vascular disease. Nat Rev Drug Discov 5, 123-132.

Nishisho, T., Hata, K., Nakanishi, M., Morita, Y., Sun-Wada, G.H., Wada, Y., Yasui, N., and Yoneda, T. (2011). The a3 isoform vacuolar type H-ATPase promotes distant metastasis in the mouse B16 melanoma cells. Mol Cancer Res 9, 845-855.

Nyberg, P., Xie, L., and Kalluri, R. (2005). Endogenous inhibitors of angiogenesis. Cancer Res 65, 3967-3979.

O'Brien, C.A., Pollett, A., Gallinger, S., and Dick, J.E. (2007). A human colon cancer cell capable of initiating tumour growth in immunodeficient mice. Nature 445, 106-110.

O'Farrell, A.M., Abrams, T.J., Yuen, H.A., Ngai, T.J., Louie, S.G., Yee, K.W., Wong, L.M., Hong, W., Lee, L.B., Town, A., et al. (2003). SU11248 is a novel FLT3 tyrosine kinase inhibitor with potent activity in vitro and in vivo. Blood 101, 3597-3605.

Oliner, J., Min, H., Leal, J., Yu, D., Rao, S., You, E., Tang, X., Kim, H., Meyer, S., Han, S.J., et al. (2004). Suppression of angiogenesis and tumor growth by selective inhibition of angiopoietin-2. Cancer Cell 6, 507-516.

Onozawa, Y., Komai, T., and Oda, T. (2011). Activation of T cell death-associated gene 8 attenuates inflammation by negatively regulating the function of inflammatory cells. Eur J Pharmacol 654, 315-319.

Orimo, A., Gupta, P.B., Sgroi, D.C., Arenzana-Seisdedos, F., Delaunay, T., Naeem, R., Carey, V.J., Richardson, A.L., and Weinberg, R.A. (2005). Stromal fibroblasts present in invasive human breast carcinomas promote tumor growth and angiogenesis through elevated SDF-1/CXCL12 secretion. Cell 121, 335-348.

Orimo, A., and Weinberg, R.A. (2006). Stromal fibroblasts in cancer: a novel tumorpromoting cell type. Cell Cycle 5, 1597-1601.

Paez-Ribes, M., Allen, E., Hudock, J., Takeda, T., Okuyama, H., Vinals, F., Inoue, M., Bergers, G., Hanahan, D., and Casanovas, O. (2009). Antiangiogenic therapy elicits malignant progression of tumors to increased local invasion and distant metastasis. Cancer Cell 15, 220-231.

Pages, F., Galon, J., Dieu-Nosjean, M.C., Tartour, E., Sautes-Fridman, C., and Fridman, W.H. (2010). Immune infiltration in human tumors: a prognostic factor that should not be ignored. Oncogene 29, 1093-1102.

Papapetropoulos, A., Garcia-Cardena, G., Dengler, T.J., Maisonpierre, P.C., Yancopoulos, G.D., and Sessa, W.C. (1999). Direct actions of angiopoietin-1 on human 
endothelium: evidence for network stabilization, cell survival, and interaction with other angiogenic growth factors. Lab Invest 79, 213-223.

Papetti, M., and Herman, I.M. (2002). Mechanisms of normal and tumor-derived angiogenesis. Am J Physiol Cell Physiol 282, C947-970.

Paradiso, A., Cardone, R.A., Bellizzi, A., Bagorda, A., Guerra, L., Tommasino, M., Casavola, V., and Reshkin, S.J. (2004). The Na+-H+ exchanger-1 induces cytoskeletal changes involving reciprocal RhoA and Rac1 signaling, resulting in motility and invasion in MDA-MB-435 cells. Breast Cancer Res 6, R616-628.

Patard, J.J., Rioux-Leclercq, N., Masson, D., Zerrouki, S., Jouan, F., Collet, N., Dubourg, C., Lobel, B., Denis, M., and Fergelot, P. (2009). Absence of VHL gene alteration and high VEGF expression are associated with tumour aggressiveness and poor survival of renal-cell carcinoma. Br J Cancer 101, 1417-1424.

Paterson, R.F., Ulbright, T.M., MacLennan, G.T., Zhang, S., Pan, C.X., Sweeney, C.J., Moore, C.R., Foster, R.S., Koch, M.O., Eble, J.N., et al. (2003). Molecular genetic alterations in the laser-capture-microdissected stroma adjacent to bladder carcinoma. Cancer 98, 1830-1836.

Pennacchietti, S., Michieli, P., Galluzzo, M., Mazzone, M., Giordano, S., and Comoglio, P.M. (2003). Hypoxia promotes invasive growth by transcriptional activation of the met protooncogene. Cancer Cell 3, 347-361.

Perez-Sayans, M., Reboiras-Lopez, M.D., Somoza-Martin, J.M., Barros-Angueira, F., Diz, P.G., Rey, J.M., and Garcia-Garcia, A. (2010). Measurement of ATP6V1C1 expression in brush cytology samples as a diagnostic and prognostic marker in oral squamous cell carcinoma. Cancer Biol Ther 9, 1057-1064.

Pertega-Gomes, N., Vizcaino, J.R., Miranda-Goncalves, V., Pinheiro, C., Silva, J., Pereira, H., Monteiro, P., Henrique, R.M., Reis, R.M., Lopes, C., et al. (2011). Monocarboxylate transporter 4 (MCT4) and CD147 overexpression is associated with poor prognosis in prostate cancer. BMC Cancer 11, 312.

Petrulio, C.A., Kim-Schulze, S., and Kaufman, H.L. (2006). The tumour microenvironment and implications for cancer immunotherapy. Expert Opin Biol Ther 6, 671-684.

Pinheiro, C., Albergaria, A., Paredes, J., Sousa, B., Dufloth, R., Vieira, D., Schmitt, F., and Baltazar, F. (2010). Monocarboxylate transporter 1 is up-regulated in basal-like breast carcinoma. Histopathology 56, 860-867.

Pinheiro, C., Longatto-Filho, A., Scapulatempo, C., Ferreira, L., Martins, S., Pellerin, L., Rodrigues, M., Alves, V.A., Schmitt, F., and Baltazar, F. (2008). Increased expression of monocarboxylate transporters 1,2, and 4 in colorectal carcinomas. Virchows Arch 452, 139-146.

Presta, L.G., Chen, H., O'Connor, S.J., Chisholm, V., Meng, Y.G., Krummen, L., Winkler, M., and Ferrara, N. (1997). Humanization of an anti-vascular endothelial growth factor monoclonal antibody for the therapy of solid tumors and other disorders. Cancer Res 57, 4593-4599.

Prince, M.E., Sivanandan, R., Kaczorowski, A., Wolf, G.T., Kaplan, M.J., Dalerba, P., Weissman, I.L., Clarke, M.F., and Ailles, L.E. (2007). Identification of a subpopulation of cells with cancer stem cell properties in head and neck squamous cell carcinoma. Proc Natl Acad Sci U S A 104, 973-978. 
Pusic, I., and DiPersio, J.F. (2010). Update on clinical experience with AMD3100, an SDF1/CXCL12-CXCR4 inhibitor, in mobilization of hematopoietic stem and progenitor cells. Curr Opin Hematol 17, 319-326.

Qiu, W., Hu, M., Sridhar, A., Opeskin, K., Fox, S., Shipitsin, M., Trivett, M., Thompson, E.R., Ramakrishna, M., Gorringe, K.L., et al. (2008). No evidence of clonal somatic genetic alterations in cancer-associated fibroblasts from human breast and ovarian carcinomas. Nat Genet 40, 650-655.

Quintana, E., Shackleton, M., Sabel, M.S., Fullen, D.R., Johnson, T.M., and Morrison, S.J. (2008). Efficient tumour formation by single human melanoma cells. Nature 456, 593-598.

Radu, C.G., Nijagal, A., McLaughlin, J., Wang, L., and Witte, O.N. (2005). Differential proton sensitivity of related $G$ protein-coupled receptors $T$ cell death-associated gene 8 and G2A expressed in immune cells. Proc Natl Acad Sci U S A 102, 1632-1637.

Rak, J., Mitsuhashi, Y., Bayko, L., Filmus, J., Shirasawa, S., Sasazuki, T., and Kerbel, R.S. (1995). Mutant ras oncogenes upregulate VEGF/VPF expression: implications for induction and inhibition of tumor angiogenesis. Cancer Res 55, 4575-4580.

Rankin, E.B., and Giaccia, A.J. (2008). The role of hypoxia-inducible factors in tumorigenesis. Cell Death Differ 15, 678-685.

Rapisarda, A., and Melillo, G. (2009). Role of the hypoxic tumor microenvironment in the resistance to anti-angiogenic therapies. Drug Resist Updat 12, 74-80.

Reshkin, S.J., Bellizzi, A., Cardone, R.A., Tommasino, M., Casavola, V., and Paradiso, A. (2003). Paclitaxel induces apoptosis via protein kinase A- and p38 mitogenactivated protein-dependent inhibition of the $\mathrm{Na}+\mathrm{H}+$ exchanger (NHE) NHE isoform 1 in human breast cancer cells. Clin Cancer Res 9, 2366-2373.

Ricci-Vitiani, L., Lombardi, D.G., Pilozzi, E., Biffoni, M., Todaro, M., Peschle, C., and De Maria, R. (2007). Identification and expansion of human colon-cancer-initiating cells. Nature 445, 111-115.

Ridgway, J., Zhang, G., Wu, Y., Stawicki, S., Liang, W.C., Chanthery, Y., Kowalski, J., Watts, R.J., Callahan, C., Kasman, I., et al. (2006). Inhibition of Dll4 signalling inhibits tumour growth by deregulating angiogenesis. Nature 444, 1083-1087.

Ridgway, P.F., Ziprin, P., Alkhamesi, N., Paraskeva, P.A., Peck, D.H., and Darzi, A.W. (2005). Hypoxia augments gelatinase activity in a variety of adenocarcinomas in vitro. J Surg Res 124, 180-186.

Righi, E., Kashiwagi, S., Yuan, J., Santosuosso, M., Leblanc, P., Ingraham, R., Forbes, B., Edelblute, B., Collette, B., Xing, D., et al. (2011). CXCL12/CXCR4 Blockade Induces Multimodal Antitumor Effects That Prolong Survival in an Immunocompetent Mouse Model of Ovarian Cancer. Cancer Res 71, 5522-5534.

Robert, C., Thomas, L., Bondarenko, I., O'Day, S., M, D.J., Garbe, C., Lebbe, C., Baurain, J.F., Testori, A., Grob, J.J., et al. (2011a). Ipilimumab plus dacarbazine for previously untreated metastatic melanoma. N Engl J Med 364, 2517-2526.

Robert, N.J., Dieras, V., Glaspy, J., Brufsky, A.M., Bondarenko, I., Lipatov, O.N., Perez, E.A., Yardley, D.A., Chan, S.Y., Zhou, X., et al. (2011b). RIBBON-1: randomized, doubleblind, placebo-controlled, phase III trial of chemotherapy with or without bevacizumab for first-line treatment of human epidermal growth factor receptor 2negative, locally recurrent or metastatic breast cancer. J Clin Oncol 29, 1252-1260. 
Rofstad, E.K., and Halsor, E.F. (2002). Hypoxia-associated spontaneous pulmonary metastasis in human melanoma xenografts: involvement of microvascular hot spots induced in hypoxic foci by interleukin 8. Br J Cancer 86, 301-308.

Ronnov-Jessen, L., Petersen, O.W., and Bissell, M.J. (1996). Cellular changes involved in conversion of normal to malignant breast: importance of the stromal reaction. Physiol Rev 76, 69-125.

Rosenberg, S.A., Yang, J.C., Sherry, R.M., Kammula, U.S., Hughes, M.S., Phan, G.Q., Citrin, D.E., Restifo, N.P., Robbins, P.F., Wunderlich, J.R., et al. (2011). Durable complete responses in heavily pretreated patients with metastatic melanoma using T-cell transfer immunotherapy. Clin Cancer Res 17, 4550-4557.

Rosenfeld, P.J., Brown, D.M., Heier, J.S., Boyer, D.S., Kaiser, P.K., Chung, C.Y., and Kim, R.Y. (2006). Ranibizumab for neovascular age-related macular degeneration. N Engl J Med 355, 1419-1431.

Rothwell, P.M., Fowkes, F.G., Belch, J.F., Ogawa, H., Warlow, C.P., and Meade, T.W. (2011). Effect of daily aspirin on long-term risk of death due to cancer: analysis of individual patient data from randomised trials. Lancet 377, 31-41.

Rothwell, P.M., Wilson, M., Elwin, C.E., Norrving, B., Algra, A., Warlow, C.P., and Meade, T.W. (2010). Long-term effect of aspirin on colorectal cancer incidence and mortality: 20-year follow-up of five randomised trials. Lancet 376, 1741-1750.

Ryan, G.B., Cliff, W.J., Gabbiani, G., Irle, C., Statkov, P.R., and Majno, G. (1973). Myofibroblasts in an avascular fibrous tissue. Lab Invest 29, 197-206.

Sahai, E. (2007). Illuminating the metastatic process. Nat Rev Cancer 7, 737-749.

Sandler, A., Gray, R., Perry, M.C., Brahmer, J., Schiller, J.H., Dowlati, A., Lilenbaum, R., and Johnson, D.H. (2006). Paclitaxel-carboplatin alone or with bevacizumab for nonsmall-cell lung cancer. N Engl J Med 355, 2542-2550.

Santisteban, M., Reiman, J.M., Asiedu, M.K., Behrens, M.D., Nassar, A., Kalli, K.R., Haluska, P., Ingle, J.N., Hartmann, L.C., Manjili, M.H., et al. (2009). Immune-induced epithelial to mesenchymal transition in vivo generates breast cancer stem cells. Cancer Res 69, 2887-2895.

Schor, S.L., Schor, A.M., Grey, A.M., and Rushton, G. (1988). Foetal and cancer patient fibroblasts produce an autocrine migration-stimulating factor not made by normal adult cells. J Cell Sci 90 ( Pt 3), 391-399.

Schwartz, D.L., Powis, G., Thitai-Kumar, A., He, Y., Bankson, J., Williams, R., Lemos, R., Oh, J., Volgin, A., Soghomonyan, S., et al. (2009). The selective hypoxia inducible factor1 inhibitor PX-478 provides in vivo radiosensitization through tumor stromal effects. Mol Cancer Ther 8, 947-958.

Seaman, S., Stevens, J., Yang, M.Y., Logsdon, D., Graff-Cherry, C., and St Croix, B. (2007). Genes that distinguish physiological and pathological angiogenesis. Cancer Cell 11, 539-554.

Semenza, G.L. (2003). Targeting HIF-1 for cancer therapy. Nat Rev Cancer 3, 721-732.

Semenza, G.L. (2007a). Evaluation of HIF-1 inhibitors as anticancer agents. Drug Discov Today $12,853-859$.

Semenza, G.L. (2007b). Hypoxia-inducible factor 1 (HIF-1) pathway. Sci STKE 2007, cm8.

Shibuya, M., and Claesson-Welsh, L. (2006). Signal transduction by VEGF receptors in regulation of angiogenesis and lymphangiogenesis. Exp Cell Res 312, 549-560. 
Shimoda, M., Mellody, K.T., and Orimo, A. (2010). Carcinoma-associated fibroblasts are a rate-limiting determinant for tumour progression. Semin Cell Dev Biol 21, 19-25.

Sin, W.C., Zhang, Y., Zhong, W., Adhikarakunnathu, S., Powers, S., Hoey, T., An, S., and Yang, J. (2004). G protein-coupled receptors GPR4 and TDAG8 are oncogenic and overexpressed in human cancers. Oncogene 23, 6299-6303.

Singh, A., and Settleman, J. (2010). EMT, cancer stem cells and drug resistance: an emerging axis of evil in the war on cancer. Oncogene 29, 4741-4751.

Singh, L.S., Berk, M., Oates, R., Zhao, Z., Tan, H., Jiang, Y., Zhou, A., Kirmani, K., Steinmetz, R., Lindner, D., et al. (2007). Ovarian cancer G protein-coupled receptor 1, a new metastasis suppressor gene in prostate cancer. J Natl Cancer Inst 99, 1313-1327.

Singh, S., Srivastava, S.K., Bhardwaj, A., Owen, L.B., and Singh, A.P. (2010). CXCL12-CXCR4 signalling axis confers gemcitabine resistance to pancreatic cancer cells: a novel target for therapy. Br J Cancer 103, 1671-1679.

Singh, S.K., Hawkins, C., Clarke, I.D., Squire, J.A., Bayani, J., Hide, T., Henkelman, R.M., Cusimano, M.D., and Dirks, P.B. (2004). Identification of human brain tumour initiating cells. Nature 432, 396-401.

Smith, J.K., Mamoon, N.M., and Duhe, R.J. (2004). Emerging roles of targeted small molecule protein-tyrosine kinase inhibitors in cancer therapy. Oncol Res 14, 175-225.

So, C.W., Karsunky, H., Wong, P., Weissman, I.L., and Cleary, M.L. (2004). Leukemic transformation of hematopoietic progenitors by MLL-GAS7 in the absence of Hoxa7 or Hoxa9. Blood 103, 3192-3199.

Solomon, S.D., McMurray, J.J., Pfeffer, M.A., Wittes, J., Fowler, R., Finn, P., Anderson, W.F., Zauber, A., Hawk, E., and Bertagnolli, M. (2005). Cardiovascular risk associated with celecoxib in a clinical trial for colorectal adenoma prevention. N Engl J Med 352, 1071-1080.

Solomon, S.D., Pfeffer, M.A., McMurray, J.J., Fowler, R., Finn, P., Levin, B., Eagle, C., Hawk, E., Lechuga, M., Zauber, A.G., et al. (2006). Effect of celecoxib on cardiovascular events and blood pressure in two trials for the prevention of colorectal adenomas. Circulation 114, 1028-1035.

Sonveaux, P., Vegran, F., Schroeder, T., Wergin, M.C., Verrax, J., Rabbani, Z.N., De Saedeleer, C.J., Kennedy, K.M., Diepart, C., Jordan, B.F., et al. (2008). Targeting lactate-fueled respiration selectively kills hypoxic tumor cells in mice. J Clin Invest 118, 3930-3942.

Steeg, P.S. (2003). Angiogenesis inhibitors: motivators of metastasis? Nat Med 9, 822-823.

Steeg, P.S. (2006). Tumor metastasis: mechanistic insights and clinical challenges. Nat Med 12, 895-904.

Steinbach, G., Lynch, P.M., Phillips, R.K., Wallace, M.H., Hawk, E., Gordon, G.B., Wakabayashi, N., Saunders, B., Shen, Y., Fujimura, T., et al. (2000). The effect of celecoxib, a cyclooxygenase-2 inhibitor, in familial adenomatous polyposis. N Engl J Med 342, 1946-1952.

Sternberg, C.N., Davis, I.D., Mardiak, J., Szczylik, C., Lee, E., Wagstaff, J., Barrios, C.H., Salman, P., Gladkov, O.A., Kavina, A., et al. (2010). Pazopanib in locally advanced or metastatic renal cell carcinoma: results of a randomized phase III trial. J Clin Oncol 28, 1061-1068. 
Sternlicht, M.D., Lochter, A., Sympson, C.J., Huey, B., Rougier, J.P., Gray, J.W., Pinkel, D., Bissell, M.J., and Werb, Z. (1999). The stromal proteinase MMP3/stromelysin-1 promotes mammary carcinogenesis. Cell 98, 137-146.

Surowiak, P., Suchocki, S., Gyorffy, B., Gansukh, T., Wojnar, A., Maciejczyk, A., Pudelko, M., and Zabel, M. (2006). Stromal myofibroblasts in breast cancer: relations between their occurrence, tumor grade and expression of some tumour markers. Folia Histochem Cytobiol 44, 111-116.

Swietach, P., Hulikova, A., Vaughan-Jones, R.D., and Harris, A.L. (2010). New insights into the physiological role of carbonic anhydrase IX in tumour $\mathrm{pH}$ regulation. Oncogene 29, 6509-6521.

Szeto, M.D., Chakraborty, G., Hadley, J., Rockne, R., Muzi, M., Alvord, E.C., Jr., Krohn, K.A., Spence, A.M., and Swanson, K.R. (2009). Quantitative metrics of net proliferation and invasion link biological aggressiveness assessed by MRI with hypoxia assessed by FMISO-PET in newly diagnosed glioblastomas. Cancer Res 69, 4502-4509.

Tennant, D.A., Duran, R.V., and Gottlieb, E. (2010). Targeting metabolic transformation for cancer therapy. Nat Rev Cancer 10, 267-277.

Thiery, J.P. (2003). Epithelial-mesenchymal transitions in development and pathologies. Curr Opin Cell Biol 15, 740-746.

Till, J.E., McCulloch, E.A., and Siminovitch, L. (1964). A Stochastic Model of Stem Cell Proliferation, Based on the Growth of Spleen Colony-Forming Cells. Proc Natl Acad Sci U S A 51, 29-36.

Tischer, E., Mitchell, R., Hartman, T., Silva, M., Gospodarowicz, D., Fiddes, J.C., and Abraham, J.A. (1991). The human gene for vascular endothelial growth factor. Multiple protein forms are encoded through alternative exon splicing. J Biol Chem 266, 11947-11954.

Tobo, M., Tomura, H., Mogi, C., Wang, J.Q., Liu, J.P., Komachi, M., Damirin, A., Kimura, T., Murata, N., Kurose, H., et al. (2007). Previously postulated "ligand-independent" signaling of GPR4 is mediated through proton-sensing mechanisms. Cell Signal 19, 1745-1753.

Tuhkanen, H., Anttila, M., Kosma, V.M., Yla-Herttuala, S., Heinonen, S., Kuronen, A., Juhola, M., Tammi, R., Tammi, M., and Mannermaa, A. (2004). Genetic alterations in the peritumoral stromal cells of malignant and borderline epithelial ovarian tumors as indicated by allelic imbalance on chromosome 3p. Int J Cancer 109, 247252.

Turturro, F., Lawson, M., Friday, E., and Welbourne, T. (2007). Targeting the $\mathrm{Na}(+) / \mathrm{H}(+)$ exchanger: an old concept with new perspectives in the treatment of hematological malignancies. Leuk Res 31, 1449-1450.

Uchida, D., Onoue, T., Kuribayashi, N., Tomizuka, Y., Tamatani, T., Nagai, H., and Miyamoto, Y. (2011). Blockade of CXCR4 in oral squamous cell carcinoma inhibits lymph node metastases. Eur J Cancer 47, 452-459.

Valable, S., Petit, E., Roussel, S., Marteau, L., Toutain, J., Divoux, D., Sobrio, F., Delamare, J., Barre, L., and Bernaudin, M. (2011). Complementary information from magnetic resonance imaging and (18)F-fluoromisonidazole positron emission tomography in the assessment of the response to an antiangiogenic treatment in a rat brain tumor model. Nucl Med Biol 38, 781-793. 
Van Cutsem, E., Vervenne, W.L., Bennouna, J., Humblet, Y., Gill, S., Van Laethem, J.L., Verslype, C., Scheithauer, W., Shang, A., Cosaert, J., et al. (2009). Phase III trial of bevacizumab in combination with gemcitabine and erlotinib in patients with metastatic pancreatic cancer. J Clin Oncol 27, 2231-2237.

Vander Heiden, M.G., Cantley, L.C., and Thompson, C.B. (2009). Understanding the Warburg effect: the metabolic requirements of cell proliferation. Science 324, 10291033.

Vavere, A.L., Biddlecombe, G.B., Spees, W.M., Garbow, J.R., Wijesinghe, D., Andreev, O.A., Engelman, D.M., Reshetnyak, Y.K., and Lewis, J.S. (2009). A novel technology for the imaging of acidic prostate tumors by positron emission tomography. Cancer Res 69, 4510-4516.

Verheul, H.M., and Pinedo, H.M. (2007). Possible molecular mechanisms involved in the toxicity of angiogenesis inhibition. Nat Rev Cancer 7, 475-485.

Walter, K., Omura, N., Hong, S.M., Griffith, M., and Goggins, M. (2008). Pancreatic cancer associated fibroblasts display normal allelotypes. Cancer Biol Ther 7, 882-888.

Wang, J.Q., Kon, J., Mogi, C., Tobo, M., Damirin, A., Sato, K., Komachi, M., Malchinkhuu, E., Murata, N., Kimura, T., et al. (2004). TDAG8 is a proton-sensing and psychosinesensitive G-protein-coupled receptor. J Biol Chem 279, 45626-45633.

Wang, Y., Liu, Y., Malek, S.N., and Zheng, P. (2011). Targeting HIF1alpha eliminates cancer stem cells in hematological malignancies. Cell Stem Cell 8, 399-411.

Warburg, O. (1956). On the origin of cancer cells. Science 123, 309-314.

Webb, B.A., Chimenti, M., Jacobson, M.P., and Barber, D.L. (2011). Dysregulated pH: a perfect storm for cancer progression. Nat Rev Cancer 11, 671-677.

Welsh, S., Williams, R., Kirkpatrick, L., Paine-Murrieta, G., and Powis, G. (2004). Antitumor activity and pharmacodynamic properties of PX-478, an inhibitor of hypoxiainducible factor-1alpha. Mol Cancer Ther 3, 233-244.

Wernert, N., Locherbach, C., Wellmann, A., Behrens, P., and Hugel, A. (2001). Presence of genetic alterations in microdissected stroma of human colon and breast cancers. Anticancer Res 21, 2259-2264.

Wilkerson, J., and Fojo, T. (2009). Progression-free survival is simply a measure of a drug's effect while administered and is not a surrogate for overall survival. Cancer J 15, 379-385.

Wilson, W.R., and Hay, M.P. (2011). Targeting hypoxia in cancer therapy. Nat Rev Cancer 11,393-410.

Xie, J., and Itzkowitz, S.H. (2008). Cancer in inflammatory bowel disease. World J Gastroenterol 14, 378-389.

Xiong, Y.Q., Sun, H.C., Zhang, W., Zhu, X.D., Zhuang, P.Y., Zhang, J.B., Wang, L., Wu, W.Z., Qin, L.X., and Tang, Z.Y. (2009). Human hepatocellular carcinoma tumor-derived endothelial cells manifest increased angiogenesis capability and drug resistance compared with normal endothelial cells. Clin Cancer Res 15, 4838-4846.

Yamagata, M., Hasuda, K., Stamato, T., and Tannock, I.F. (1998). The contribution of lactic acid to acidification of tumours: studies of variant cells lacking lactate dehydrogenase. Br J Cancer 77, 1726-1731.

Yang, L.V., Radu, C.G., Roy, M., Lee, S., McLaughlin, J., Teitell, M.A., Iruela-Arispe, M.L., and Witte, O.N. (2007). Vascular abnormalities in mice deficient for the G proteincoupled receptor GPR4 that functions as a pH sensor. Mol Cell Biol 27, 1334-1347. 
You, H., Jin, J., Shu, H., Yu, B., De Milito, A., Lozupone, F., Deng, Y., Tang, N., Yao, G., Fais, S., et al. (2009). Small interfering RNA targeting the subunit ATP6L of proton pump V-ATPase overcomes chemoresistance of breast cancer cells. Cancer Lett 280, 110119.

You, W.K., and McDonald, D.M. (2008). The hepatocyte growth factor/c-Met signaling pathway as a therapeutic target to inhibit angiogenesis. BMB Rep 41, 833-839.

Zatovicova, M., Jelenska, L., Hulikova, A., Csaderova, L., Ditte, Z., Ditte, P., Goliasova, T., Pastorek, J., and Pastorekova, S. (2010). Carbonic anhydrase IX as an anticancer therapy target: preclinical evaluation of internalizing monoclonal antibody directed to catalytic domain. Curr Pharm Des 16, 3255-3263.

Zeisberg, M., Strutz, F., and Muller, G.A. (2000). Role of fibroblast activation in inducing interstitial fibrosis. J Nephrol 13 Suppl 3, S111-120.

Zhang, F., and Aft, R.L. (2009). Chemosensitizing and cytotoxic effects of 2-deoxy-D-glucose on breast cancer cells. J Cancer Res Ther 5 Suppl 1, S41-43.

Zhao, B.C., Wang, Z.J., Mao, W.Z., Ma, H.C., Han, J.G., Zhao, B., and Xu, H.M. (2011). CXCR4/SDF-1 axis is involved in lymph node metastasis of gastric carcinoma. World J Gastroenterol 17, 2389-2396. 


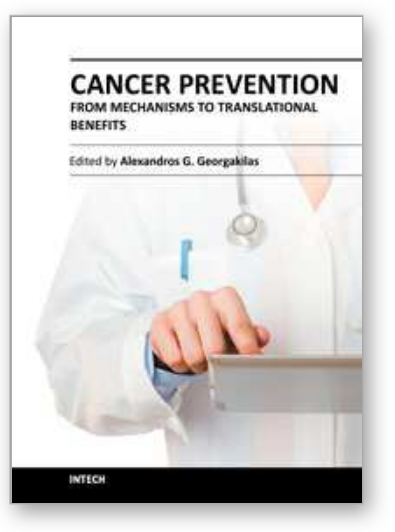

\author{
Cancer Prevention - From Mechanisms to Translational Benefits \\ Edited by Dr. Alexandros G. Georgakilas
}

ISBN 978-953-51-0547-3

Hard cover, 476 pages

Publisher InTech

Published online 20, April, 2012

Published in print edition April, 2012

This unique synthesis of chapters from top experts in their fields targets the unique and significant area of cancer prevention for different types of cancers. Perspective readers are invited to go through novel ideas and current developments in the field of molecular mechanisms for cancer prevention, epidemiological studies, antioxidant therapies and diets, as well as clinical aspects and new advances in prognosis and avoidance of cancer. The primary target audience for the book includes PhD students, researchers, biologists, medical doctors and professionals who are interested in mechanistic studies on cancer prevention and translational benefits for optimized cancer treatment.

\title{
How to reference
}

In order to correctly reference this scholarly work, feel free to copy and paste the following:

Li V. Yang, Reid D. Castellone and Lixue Dong (2012). Targeting Tumor Microenvironments for Cancer Prevention and Therapy, Cancer Prevention - From Mechanisms to Translational Benefits, Dr. Alexandros G. Georgakilas (Ed.), ISBN: 978-953-51-0547-3, InTech, Available from:

http://www.intechopen.com/books/cancer-prevention-from-mechanisms-to-translational-benefits/targetingtumor-microenvironments-for-cancer-prevention-and-therapy

\section{INTECH}

open science | open minds

\section{InTech Europe}

University Campus STeP Ri

Slavka Krautzeka 83/A

51000 Rijeka, Croatia

Phone: +385 (51) 770447

Fax: +385 (51) 686166

www.intechopen.com

\section{InTech China}

Unit 405, Office Block, Hotel Equatorial Shanghai

No.65, Yan An Road (West), Shanghai, 200040, China

中国上海市延安西路65号上海国际贵都大饭店办公楼 405 单元

Phone: +86-21-62489820

Fax: $+86-21-62489821$ 
(C) 2012 The Author(s). Licensee IntechOpen. This is an open access article distributed under the terms of the Creative Commons Attribution 3.0 License, which permits unrestricted use, distribution, and reproduction in any medium, provided the original work is properly cited. 